Cite this: Phys. Chem. Chem. Phys. 2014, 16, 1139

Received 16th October 2013, Accepted 19th November 2013 DOI: $10.1039 / c 3 c p 54391 a$

www.rsc.org/pccp

\title{
Kinetics of $\mathrm{CH}_{2} \mathrm{OO}$ reactions with $\mathrm{SO}_{2}, \mathrm{NO}_{2}, \mathrm{NO}$, $\mathrm{H}_{2} \mathrm{O}$ and $\mathrm{CH}_{3} \mathrm{CHO}$ as a function of pressure $\uparrow$
}

\begin{abstract}
Daniel Stone, ${ }^{a}$ Mark Blitz, ${ }^{\star a b}$ Laura Daubney, ${ }^{a}$ Neil U. M. Howes ${ }^{a}$ and Paul Seakins ${ }^{a b}$
Kinetics of $\mathrm{CH}_{2} \mathrm{OO}$ Criegee intermediate reactions with $\mathrm{SO}_{2}, \mathrm{NO}_{2}, \mathrm{NO}, \mathrm{H}_{2} \mathrm{O}$ and $\mathrm{CH}_{3} \mathrm{CHO}$ and $\mathrm{CH}_{2} \mathrm{l}$ radical reactions with $\mathrm{NO}_{2}$ are reported as a function of pressure at $295 \mathrm{~K}$. Measurements were made under pseudo-first-order conditions using flash photolysis of $\mathrm{CH}_{2} \mathrm{I}_{2}-\mathrm{O}_{2}-\mathrm{N}_{2}$ gas mixtures in the presence of excess co-reagent combined with monitoring of $\mathrm{HCHO}$ reaction products by laser-induced fluorescence (LIF) spectroscopy and, for the reaction with $\mathrm{SO}_{2}$, direct detection of $\mathrm{CH}_{2} \mathrm{OO}$ by photoionisation mass spectrometry (PIMS). Rate coefficients for $\mathrm{CH}_{2} \mathrm{OO}+\mathrm{SO}_{2}$ and $\mathrm{CH}_{2} \mathrm{OO}+\mathrm{NO}_{2}$ are independent of pressure in the ranges studied and are $(3.42 \pm 0.42) \times 10^{-11} \mathrm{~cm}^{3} \mathrm{~s}^{-1}$ (measured between 1.5 and 450 Torr) and (1.5 \pm 0.5$) \times$ $10^{-12} \mathrm{~cm}^{3} \mathrm{~s}^{-1}$ (measured between 25 and 300 Torr), respectively. The rate coefficient for $\mathrm{CH}_{2} \mathrm{OO}+\mathrm{CH}_{3} \mathrm{CHO}$ is pressure dependent, with the yield of $\mathrm{HCHO}$ decreasing with increasing pressure. Upper limits of $2 \times$ $10^{-13} \mathrm{~cm}^{3} \mathrm{~s}^{-1}$ and $9 \times 10^{-17} \mathrm{~cm}^{3} \mathrm{~s}^{-1}$ are placed on the rate coefficients for $\mathrm{CH}_{2} \mathrm{OO}+\mathrm{NO}$ and $\mathrm{CH}_{2} \mathrm{OO}+$ $\mathrm{H}_{2} \mathrm{O}$, respectively. The upper limit for the rate coefficient for $\mathrm{CH}_{2} \mathrm{OO}+\mathrm{H}_{2} \mathrm{O}$ is significantly lower than has been reported previously, with consequences for modelling of atmospheric impacts of $\mathrm{CH}_{2} \mathrm{OO}$ chemistry.
\end{abstract}

\section{Introduction}

Criegee intermediates, carbonyl oxide biradicals with the general formula $\mathrm{CR}_{2} \mathrm{OO}$, are principally produced in the atmosphere following ozonolysis of unsaturated volatile organic compounds (VOCs) and are key species in the tropospheric oxidation of both biogenic and anthropogenic compounds. ${ }^{1,2}$ The exothermicity of ozonolysis reactions leads to production of vibrationally excited Criegee intermediates with sufficient energy to undergo unimolecular decomposition to products including $\mathrm{OH}$ and $\mathrm{HO}_{2},{ }^{3-6}$ representing a significant source of these key oxidising species in certain important environments. ${ }^{7-9}$ However, collisional quenching of the nascent excited Criegee intermediate by $\mathrm{N}_{2}$ or $\mathrm{O}_{2}$, to produce stabilised Criegee intermediates, is competitive with the unimolecular decomposition processes at ambient pressures, ${ }^{1,5}$ and reactions of stabilised Criegee intermediates have the potential to impact atmospheric budgets of $\mathrm{NO}_{x}\left(\mathrm{NO}_{x}=\right.$ $\left.\mathrm{NO}+\mathrm{NO}_{2}\right), \mathrm{NO}_{3}, \mathrm{O}_{3}, \mathrm{HO}_{x}\left(\mathrm{HO}_{x}=\mathrm{OH}+\mathrm{HO}_{2}\right), \mathrm{SO}_{2}, \mathrm{H}_{2} \mathrm{SO}_{4}$, sulfate aerosol and secondary organic aerosol (SOA)..$^{5,10-17}$

Despite their potential importance in atmospheric chemistry, and thus in the assessment and prediction of issues such as air quality and climate change, direct observations of Criegee intermediates have only recently been achieved. ${ }^{10-12,18-20}$ Kinetics and product yields of Criegee intermediate reactions currently

\footnotetext{
${ }^{a}$ School of Chemistry, University of Leeds, Leeds, UK. E-mail: m.blitz@leeds.ac.uk

${ }^{b}$ National Centre for Atmospheric Science, University of Leeds, Leeds, UK

$\dagger$ Electronic supplementary information (ESI) available. See DOI: 10.1039/ c3cp54391a
}

used in atmospheric models are subject to large uncertainties, owing to the reliance of previous investigations on indirect techniques involving measurements of stable species in complex ozonolysis experiments, in which there are several potential sources and sinks of the measured species. ${ }^{1,2}$ Welz et al. ${ }^{10}$ reported the first direct measurements of Criegee intermediate kinetics, where the photolysis of $\mathrm{CH}_{2} \mathrm{I}_{2}$ in the presence of $\mathrm{O}_{2}$ was used to generate the $\mathrm{CH}_{2} \mathrm{OO}$ Criegee intermediate at low pressure (4 Torr) and, using synchrotron photoionisation mass spectrometry (PIMS) at the Advanced Light Source (ALS), demonstrated unequivocally that the Criegee intermediate, $\mathrm{CH}_{2} \mathrm{OO}$, was being monitored:

$$
\begin{gathered}
\mathrm{CH}_{2} \mathrm{I}_{2}+h \nu \rightarrow \mathrm{CH}_{2} \mathrm{I}+\mathrm{I} \\
\mathrm{CH}_{2} \mathrm{I}+\mathrm{O}_{2} \rightarrow \mathrm{CH}_{2} \mathrm{OO}+\mathrm{I}
\end{gathered}
$$

While reactions of $\mathrm{CH}_{2} \mathrm{OO}$ with $\mathrm{NO}$ and water vapour were reported to be slow, the reactions of $\mathrm{CH}_{2} \mathrm{OO}$ with $\mathrm{SO}_{2}$ and $\mathrm{NO}_{2}$ were shown to be significantly faster than indicated by the indirect methods. Rate coefficients for both $\mathrm{CH}_{2} \mathrm{OO}+\mathrm{SO}_{2}$ and $\mathrm{CH}_{2} \mathrm{OO}+\mathrm{NO}_{2}$, measured at a pressure of 4 Torr and temperature of $298 \mathrm{~K}$, were both approximately 1000 times greater than previously assigned, implying a more significant role of Criegee intermediate chemistry in the atmosphere than expected.

The ability to produce $\mathrm{CH}_{2} \mathrm{OO}$ following photolysis of $\mathrm{CH}_{2} \mathrm{I}_{2}$ in the presence of $\mathrm{O}_{2}{ }^{10}$ has also facilitated spectroscopic investigations of $\mathrm{CH}_{2} \mathrm{OO}$ in the infrared ${ }^{19}$ and ultraviolet, ${ }^{20}$ and has been used to demonstrate the production of $\mathrm{NO}_{3}$ in the reaction of $\mathrm{CH}_{2} \mathrm{OO}$ with $\mathrm{NO}_{2} \cdot{ }^{21}$ Subsequent work at the ALS has 
investigated the reactions of $\mathrm{CH}_{2} \mathrm{OO}$ with acetone, acetaldehyde and hexafluoroacetone at low pressures, ${ }^{11}$ with theoretical investigation $^{22}$ of the reaction between $\mathrm{CH}_{2} \mathrm{OO}$ and acetaldehyde $\left(\mathrm{CH}_{3} \mathrm{CHO}\right)$ indicating pressure dependence of the reaction and collisional stabilisation of nascent reaction adducts to produce secondary ozonides (SOZs) at higher pressures which subsequently decompose to generate organic acids.

Taatjes et al. $^{12}$ have also recently demonstrated production of the $\mathrm{CH}_{3} \mathrm{CHOO}$ Criegee intermediate following photolysis of $\mathrm{CH}_{3} \mathrm{CHI}_{2}$ in the presence of $\mathrm{O}_{2}$. The structure of the $\mathrm{CH}_{3} \mathrm{CHOO}$ Criegee intermediate gives rise to the possibility of syn- and anti-conformers, with the conformers sufficiently different in energy, and with a barrier to conversion, leading to the potential for their behaviour as distinct species. Using the synchrotron PIMS technique, Taatjes et $a .^{12}$ were not only able to identify both the syn- and anti- $\mathrm{CH}_{3} \mathrm{CHOO}$ conformers, but were also able to assign separate rate coefficients for reactions of the two conformers with $\mathrm{SO}_{2}$ and water vapour. The anti-conformer was shown to display greater reactivity towards both $\mathrm{SO}_{2}$ and $\mathrm{H}_{2} \mathrm{O}$ compared to the synconformer, with rate coefficients for reactions of both syn- and anticonformers with $\mathrm{SO}_{2}$ greater than previously expected. ${ }^{12}$

Field observations in a boreal forest in Finland have provided further evidence for rapid reactions between Criegee intermediates and $\mathrm{SO}_{2}$, with measurements identifying the presence of oxidising species other than $\mathrm{OH}$ which are able to oxidise $\mathrm{SO}_{2}$ to $\mathrm{SO}_{3}$ and ultimately to produce $\mathrm{H}_{2} \mathrm{SO}_{4} \cdot{ }^{23}$ The presence of the unknown oxidising species was shown to be related to emissions of biogenic alkenes, and it was postulated that Criegee intermediates may be responsible, with laboratory measurements of $\mathrm{H}_{2} \mathrm{SO}_{4}$ production during alkene ozonolysis reactions in the presence of $\mathrm{SO}_{2}$ and $\mathrm{OH}$ scavengers providing further support for the action of Criegee intermediates as atmospheric oxidants of $\mathrm{SO}_{2} \cdot{ }^{23}$

Implementation of increased Criegee intermediate $+\mathrm{SO}_{2}$ reaction rates in atmospheric models has been shown to improve model simulations of $\mathrm{H}_{2} \mathrm{SO}_{4}$ in forested regions in Finland and Germany, ${ }^{14}$ and global modelling has shown that while global production of $\mathrm{H}_{2} \mathrm{SO}_{4}$ increases by only $4 \%$, there are increases of up to $100 \%$ in the boundary layer in tropical forests. ${ }^{15}$ Further modelling work has shown that reactions of Criegee intermediates with $\mathrm{SO}_{2}$ can compete with $\mathrm{OH}+\mathrm{SO}_{2}$ in a number of regions, and that Criegee $+\mathrm{SO}_{2}$ reactions may be the dominant removal mechanism for $\mathrm{SO}_{2}$ in certain areas and are major contributors to sulfate aerosol formation on a regional scale. ${ }^{17}$ Air quality modelling over the U.S. displayed limited impacts of increased Criegee $+\mathrm{SO}_{2}$ reaction rates on sulfate aerosol production in this region, but the impacts were shown to be highly dependent on the competition between Criegee $+\mathrm{SO}_{2}$ and Criegee $+\mathrm{H}_{2} \mathrm{O}$, with a combination of increased Criegee $+\mathrm{SO}_{2}$ and decreased Criegee $+\mathrm{H}_{2} \mathrm{O}$ reaction rates leading to enhanced sulfate aerosol concentrations. ${ }^{16}$ However, such studies have largely been based on the low pressure data for $\mathrm{CH}_{2} \mathrm{OO}+\mathrm{SO}_{2}$ reported by Welz et al. ${ }^{10}$ and there is considerable uncertainty regarding the upper limit for $\mathrm{CH}_{2} \mathrm{OO}+\mathrm{H}_{2} \mathrm{O}{ }^{2,17}$

Theoretical work has provided support for rapid reactions between Criegee intermediates and $\mathrm{SO}_{2},{ }^{13,24}$ with reactions proceeding via the initial barrierless formation of a cyclic secondary ozonide, and has enabled prediction of potential effects of pressure. ${ }^{13}$ For $\mathrm{CH}_{2} \mathrm{OO}+\mathrm{SO}_{2}$, it has been predicted that the reaction products at atmospheric pressure will be a mixture of $\mathrm{HCHO}+\mathrm{SO}_{3}(\sim 68 \%)$, formyl sulfinic ester $(\mathrm{HC}(\mathrm{O}) \mathrm{OS}(\mathrm{O}) \mathrm{OH})(\sim 15 \%)$ and a singlet bisoxy diradical $\left(\mathrm{CH}_{2}(\mathrm{O}) \mathrm{O}\right)+\mathrm{SO}_{2}(\sim 17 \%) .{ }^{13}$ In contrast, reactions of larger Criegee intermediates, including $\mathrm{CH}_{3} \mathrm{CHOO}$, at ambient pressures are expected to result in production of stabilised secondary ozonide species, with little formation of $\mathrm{SO}_{3}$, and therefore little impact on $\mathrm{H}_{2} \mathrm{SO}_{4}$ and sulfate aerosol. ${ }^{13}$ Investigation of the reaction products and pressure dependence of Criegee intermediate reactions is thus essential to the accurate determination of their atmospheric impacts.

The yield of $\mathrm{CH}_{2} \mathrm{OO}$ Criegee intermediates following $\mathrm{CH}_{2} \mathrm{I}_{2}$ photolysis in $\mathrm{O}_{2}$ was studied by Huang et al., ${ }^{25}$ and in our previous work, ${ }^{26}$ as a function of pressure. Both investigations indicate that the initial reaction between $\mathrm{CH}_{2} \mathrm{I}$ radicals and $\mathrm{O}_{2}$ (R2) produces a chemically activated species, $\mathrm{CH}_{2} \mathrm{IO}_{2}{ }^{\#}$, which decomposes at low pressures to produce $\mathrm{CH}_{2} \mathrm{OO}+\mathrm{I}(\mathrm{R} 2 \mathrm{a})$, but is collisionally stabilised at higher pressures to produce the $\mathrm{CH}_{2} \mathrm{IO}_{2}$ peroxy radical (R2b).

$$
\begin{gathered}
\mathrm{CH}_{2} \mathrm{I}_{2}+h \nu \rightarrow \mathrm{CH}_{2} \mathrm{I}+\mathrm{I} \\
\mathrm{CH}_{2} \mathrm{I}+\mathrm{O}_{2} \rightarrow \mathrm{CH}_{2} \mathrm{IO}_{2}^{\#} \\
\mathrm{CH}_{2} \mathrm{IO}_{2}^{\#} \rightarrow \mathrm{CH}_{2} \mathrm{OO}+\mathrm{I} \\
\mathrm{CH}_{2} \mathrm{IO}_{2}^{\#}+\mathrm{M} \rightarrow \mathrm{CH}_{2} \mathrm{IO}_{2}+\mathrm{M}
\end{gathered}
$$

Our previous work ${ }^{26}$ indicates a yield of $\sim 18 \% \mathrm{CH}_{2} \mathrm{OO}$ following photolysis of $\mathrm{CH}_{2} \mathrm{I}_{2}$ in air at 760 Torr, with recent results from Huang et $a l^{27}$ in reasonable agreement. This result has potential significance for modelling of atmospheric chemistry in iodine-rich regions, ${ }^{28-31}$ and also indicates potential for pressure dependent studies of $\mathrm{CH}_{2} \mathrm{OO}$ kinetics using photolysis of $\mathrm{CH}_{2} \mathrm{I}_{2}$ in $\mathrm{O}_{2}$.

In this work, we report kinetics of $\mathrm{CH}_{2} \mathrm{OO}$ reactions with $\mathrm{SO}_{2}, \mathrm{NO}_{2}, \mathrm{NO}, \mathrm{H}_{2} \mathrm{O}$ and $\mathrm{CH}_{3} \mathrm{CHO}$ at pressures between 25 and 450 Torr at a temperature of $295 \mathrm{~K}$, using photolysis of $\mathrm{CH}_{2} \mathrm{I}_{2}-\mathrm{O}_{2}-\mathrm{N}_{2}$ mixtures under pseudo-first-order conditions combined with monitoring of the $\mathrm{HCHO}$ reaction products by laser-induced fluorescence (LIF) spectroscopy, and, for the $\mathrm{CH}_{2} \mathrm{OO}+\mathrm{SO}_{2}$ reaction at $\sim 1.5$ Torr, direct monitoring of $\mathrm{CH}_{2} \mathrm{OO}$ by photoionisation mass spectrometry (PIMS). We also report kinetics of the $\mathrm{CH}_{2} \mathrm{I}+\mathrm{NO}_{2}$ reaction at pressures between 25 and 300 Torr at $295 \mathrm{~K}$.

\section{Experimental}

\subsection{Laser-induced fluorescence experiments}

Apparatus and experimental procedures for the laser-induced fluorescence (LIF) experiments have been described elsewhere in detail, ${ }^{26,32}$ therefore only a brief description is given here. Kinetics of $\mathrm{CH}_{2} \mathrm{OO}$ reactions were studied by monitoring of HCHO reaction products by LIF spectroscopy. Radicals were generated by the laser flash photolysis of $\mathrm{CH}_{2} \mathrm{I}_{2}-\mathrm{O}_{2}-\mathrm{N}_{2}$ gas mixtures (R1 and R2) with the addition of excess co-reagent 
$\left(\mathrm{NO}_{2}, \mathrm{NO}, \mathrm{SO}_{2}, \mathrm{H}_{2} \mathrm{O}\right.$ or $\left.\mathrm{CH}_{3} \mathrm{CHO}\right)$ to ensure pseudo-first-order conditions. Experiments to investigate $\mathrm{CH}_{2} \mathrm{I}+\mathrm{NO}_{2}$ kinetics were performed in the absence of $\mathrm{O}_{2}$, while those to investigate $\mathrm{CH}_{2} \mathrm{OO}+\mathrm{NO}_{2}$ were performed using a limited range of $\mathrm{NO}_{2}$ concentrations in order to avoid production of $\mathrm{HCHO}$ through the reaction of $\mathrm{CH}_{2}$ I with $\mathrm{NO}_{2}$ (see Section 3.1), whilst maintaining pseudo-first-order conditions.

$\mathrm{CH}_{2} \mathrm{I}_{2}$ (Sigma-Aldrich, 99\%) was used as a dilute gas in $\mathrm{N}_{2}$ either by filling a glass bulb containing liquid $\mathrm{CH}_{2} \mathrm{I}_{2}$ with $\mathrm{N}_{2}$ or by bubbling a slow flow of $\mathrm{N}_{2}$ through liquid $\mathrm{CH}_{2} \mathrm{I}_{2}$. Reagents (NO, $\mathrm{NO}_{2}, \mathrm{SO}_{2}, \mathrm{CH}_{3} \mathrm{CHO}$ ) were prepared at known concentrations in $\mathrm{N}_{2}$ and stored in glass bulbs. NO (BOC Special Gases, 99.5\%) was purified prior to use by a series of freeze-pumpthaw cycles. $\mathrm{CH}_{2} \mathrm{I}_{2}, \mathrm{CH}_{3} \mathrm{CHO}$ (Sigma-Aldrich, 99.5\%), $\mathrm{NO}_{2}$ (Sigma-Aldrich, 99.5\%), $\mathrm{SO}_{2}$ (Sigma-Aldrich, 99.9\%), $\mathrm{N}_{2}$ (BOC, 99.99\%) and $\mathrm{O}_{2}$ (BOC, 99.999\%) were used as supplied. Water vapour was added to the gas mixture by bubbling a known flow of $\mathrm{N}_{2}$ gas through a bubbler containing deionised water at a known temperature. Gases were mixed in a gas manifold and passed into a six-way cross reaction cell at known flow rates (determined by calibrated mass flow controllers). The pressure in the reaction cell was monitored by a capacitance manometer (MKS Instruments, 626A) and controlled by throttling the exit valve to the reaction cell. The total gas flow rate through the reaction cell was adjusted with total pressure to maintain an approximately constant gas residence time in the cell $(\sim 0.1 \mathrm{~s})$. All experiments were performed at $T=(295 \pm 2) \mathrm{K}$ unless stated otherwise.

For experiments using $\mathrm{NO}_{2}, \mathrm{NO}, \mathrm{CH}_{3} \mathrm{CHO}$ or $\mathrm{H}_{2} \mathrm{O}$ as co-reagents, initiation of chemistry within the cell was achieved using an excimer laser (KrF, Tui ExciStar M) operating at $\lambda=248 \mathrm{~nm}$ with typical laser fluence in the range $30-80 \mathrm{~mJ} \mathrm{~cm}^{-2}$. Experiments in which $\mathrm{SO}_{2}$ was present as the co-reagent were performed at a photolysis wavelength of $355 \mathrm{~nm}$ (typical fluence $\sim 150 \mathrm{~mJ} \mathrm{~cm}^{-2}$ ), generated by frequency tripling the output of a Nd:YAG laser (Spectron Laser Systems) to avoid potential multi-photon photolysis of $\mathrm{SO}_{2}$ at shorter wavelengths. ${ }^{33-35}$

Production of $\mathrm{HCHO}$ was monitored by laser-induced fluorescence (LIF) of HCHO at $\lambda \sim 353.1 \mathrm{~nm} .{ }^{36}$ Approximately 2 to $4 \mathrm{~mJ}$ pulse $^{-1}$ of laser light at $\sim 353.1 \mathrm{~nm}$ was generated by a dye laser (Lambda Physik, FL3002) operating on DMQ/ dioxirane dye and pumped by a $308 \mathrm{~nm}$ excimer laser generating $\sim 50 \mathrm{~mJ}$ pulse $^{-1}$ (XeCl, Lambda Physik LPX100). The output of the dye laser was passed through the reaction cell in an orthogonal axis to the $248 \mathrm{~nm} / 355 \mathrm{~nm}$ photolysis laser output, with $\mathrm{HCHO}$ fluorescence detected in the visible region of the spectrum by a channel photomultiplier (CPM, Perkin-Elmer C1943P) orthogonal to both the photolysis laser and the LIF excitation laser beams. A Perspex filter was used to prevent scattered laser light from the photolysis laser and the LIF excitation laser reaching the CPM. The HCHO fluorescence signal was monitored as a function of time following photolysis of $\mathrm{CH}_{2} \mathrm{I}_{2}$ by varying the time delay between firing the photolysis laser and the LIF excitation laser through use of a delay generator (SRS DG535). Results from between 5 and 20 photolysis shots were typically averaged prior to analysis.

\subsection{Photoionisation mass spectrometry experiments}

Photoionisation mass spectrometry (PIMS) experiments were performed in this work to determine the kinetics of $\mathrm{CH}_{2} \mathrm{OO}+\mathrm{SO}_{2}$ at low pressure ( $\sim 1.5$ Torr) and $295 \mathrm{~K}$ by direct monitoring of $\mathrm{CH}_{2} \mathrm{OO}$ in reactions performed under pseudo-first-order conditions. The PIMS apparatus has been described previously in detail ${ }^{32,37,38}$ and only a brief description is given here. Gas mixtures of $\mathrm{CH}_{2} \mathrm{I}_{2}-\mathrm{O}_{2}-\mathrm{N}_{2}$ and $\mathrm{CH}_{2} \mathrm{I}_{2}-\mathrm{O}_{2}-\mathrm{N}_{2}-\mathrm{SO}_{2}$ were prepared in a gas handling line, with reagents and reagent preparation as described above for the LIF experiments, and introduced to the steel reaction flow tube (10.5 mm internal diameter, $70 \mathrm{~cm}$ in length) via calibrated mass flow controllers. The pressure in the reaction flow tube was monitored by a capacitance manometer (MKS Instruments, 626A) and controlled by throttling the exit valve to the flow tube.

Chemistry was initiated by a pulsed excimer laser (Lambda Physik, Compex 205) at a wavelength of $248 \mathrm{~nm}$, with typical fluence of $\sim 50 \mathrm{~mJ} \mathrm{~cm}^{-2}$, through reactions (R1) and (R2). A representative sample from the reaction mixture effused into a high vacuum chamber $\left(<10^{-5}\right.$ Torr, maintained by diffusion and turbo pumps) via a $1 \mathrm{~mm}$ pinhole situated in the sidewall of the reaction flow tube. Components of the gas mixture were photoionised using $118 \mathrm{~nm}$ vacuum ultraviolet (VUV) laser light (typically $10^{11}$ photons pulse ${ }^{-1}$ ), generated by frequency tripling of the third harmonic of a Nd:YAG laser (Continuum Powerlite, 8010) in a Xe gas cell, and passed across the effusing gas flow within 2-3 mm of the sampling pinhole. VUV light of $118 \mathrm{~nm}$ (equivalent to $10.5 \mathrm{eV}$ ) is sufficiently energetic to ionise $\mathrm{CH}_{2} \mathrm{OO}$ (threshold = $10.02 \mathrm{eV}$ ), but is below the threshold required to ionise other isomers at $\mathrm{m} / \mathrm{z}=46$ (dioxirane, threshold $=10.82 \mathrm{eV}$; formic acid, threshold $=11.33 \mathrm{eV}) .{ }^{10}$ Ions were sampled by the time of flight mass spectrometer (TOF-MS, Kore Technology Ltd), and detected by an electron multiplier. The ion signals were amplified and boxcar averaged on an oscilloscope and then stored on the control computer. The ion signals were monitored as a function of time following photolysis of $\mathrm{CH}_{2} \mathrm{I}_{2}$ by varying the time delay between the excimer laser and the Nd:YAG laser, used to generate the VUV radiation, through use of a delay generator (SRS DG35). These kinetic traces consisted of typically 200 time points, with typically between 10 and 25 shot averaging per time point.

\section{Results and discussion}

\subsection{Photolysis of $\mathrm{CH}_{2} \mathrm{I}_{2}-\mathrm{O}_{2}-\mathrm{N}_{2}$ mixtures}

Fig. 1 shows the HCHO fluorescence signal following photolysis of $\mathrm{CH}_{2} \mathrm{I}_{2}-\mathrm{O}_{2}-\mathrm{N}_{2}$ mixtures (i.e. in the absence of any additional co-reagent), resulting in production of $\mathrm{HCHO}$ through reactions (R1)-(R6): ${ }^{26,32}$

$$
\begin{gathered}
\mathrm{CH}_{2} \mathrm{I}_{2}+h \nu \rightarrow \mathrm{CH}_{2} \mathrm{I}+\mathrm{I} \\
\mathrm{CH}_{2} \mathrm{I}+\mathrm{O}_{2} \rightarrow \mathrm{CH}_{2} \mathrm{OO}+\mathrm{I} \\
\mathrm{CH}_{2} \mathrm{I}+\mathrm{O}_{2}+\mathrm{M} \rightarrow \mathrm{CH}_{2} \mathrm{IO}_{2}+\mathrm{M} \\
\mathrm{CH}_{2} \mathrm{OO}+\mathrm{I} \rightarrow \mathrm{HCHO}+\mathrm{IO} \\
\mathrm{CH}_{2} \mathrm{IO}_{2}+\mathrm{I} \rightarrow \mathrm{CH}_{2} \mathrm{IO}+\mathrm{IO}
\end{gathered}
$$




$$
\begin{gathered}
\mathrm{CH}_{2} \mathrm{IO}_{2}+\mathrm{CH}_{2} \mathrm{IO}_{2} \rightarrow 2 \mathrm{CH}_{2} \mathrm{IO}+\mathrm{O}_{2} \\
\mathrm{CH}_{2} \mathrm{IO} \rightarrow \mathrm{HCHO}+\mathrm{I}
\end{gathered}
$$

Previous work in this laboratory ${ }^{26}$ has shown that the yields of $\mathrm{CH}_{2} \mathrm{OO}$ and $\mathrm{CH}_{2} \mathrm{IO}_{2}$ from (R2) are dependent on pressure, owing to initial formation of the excited species $\mathrm{CH}_{2} \mathrm{IO}_{2}{ }^{\#}$, which can either decompose to produce the $\mathrm{CH}_{2} \mathrm{OO}$ Criegee intermediate and iodine atoms (R2a) or can be collisionally stabilised to produce the peroxy radical $\mathrm{CH}_{2} \mathrm{IO}_{2}(\mathrm{R} 2 \mathrm{~b})$. Since subsequent reactions of both $\mathrm{CH}_{2} \mathrm{OO}$ and $\mathrm{CH}_{2} \mathrm{IO}_{2}$ in the absence of any additional co-reagent result in production of $\mathrm{HCHO}$, there is no change in the total $\mathrm{HCHO}$ yield as a function of pressure following photolysis of $\mathrm{CH}_{2} \mathrm{I}_{2}-\mathrm{O}_{2}-\mathrm{N}_{2}$ mixtures.

Production of HCHO in reactions (R1)-(R6) can be approximated by eqn $(1):{ }^{26,32}$

$$
\begin{aligned}
S_{\mathrm{HCHO}, t}= & S_{0}\left[\exp \left(-k_{\text {loss }} t\right)\right] \\
& +\frac{S_{1} k_{\mathrm{g}}{ }^{\prime}}{k_{\mathrm{g}}{ }^{\prime}-k_{\text {loss }}}\left[\exp \left(-k_{\text {loss }} t\right)-\exp \left(-k_{\mathrm{g}}{ }^{\prime} t\right)\right]
\end{aligned}
$$

where $S_{\mathrm{HCHO}, t}$ is the HCHO signal at time $t, S_{0}$ is the height of the HCHO signal at time zero, $S_{1}$ is the maximum $\mathrm{HCHO}$ signal, $k_{\mathrm{g}}{ }^{\prime}$ is the pseudo-first-order rate coefficient for HCHO growth, and $k_{\text {loss }}$ is the rate coefficient representing the slow loss of $\mathrm{HCHO}$ from the detection region via diffusion. Although the HCHO growth through reactions (R1)-(R6) is not strictly first-order, our previous work ${ }^{26}$ demonstrates that eqn (1) can faithfully reproduce the $\mathrm{HCHO}$ growth kinetics. In the presence of excess co-reagent (e.g. $\mathrm{SO}_{2}, \mathrm{NO}_{2}$ ) the kinetics of $\mathrm{HCHO}$ production from $\mathrm{CH}_{2} \mathrm{OO}$ are under pseudo-first-order conditions. Fig. 1 shows the fits to $\mathrm{HCHO}$ production in the absence and presence of additional co-reagent, indicating the fidelity of the fit to the analytical equation.

In the absence of any additional co-reagent, the first-order rate coefficient approximating the production of $\mathrm{HCHO}, k_{\mathrm{g}}{ }^{\prime}$, was found to vary from $\sim 300 \mathrm{~s}^{-1}$ to $\sim 3500 \mathrm{~s}^{-1}$, depending on the concentration of $\mathrm{CH}_{2} \mathrm{I}_{2}$, and thus of I atoms, in the system,

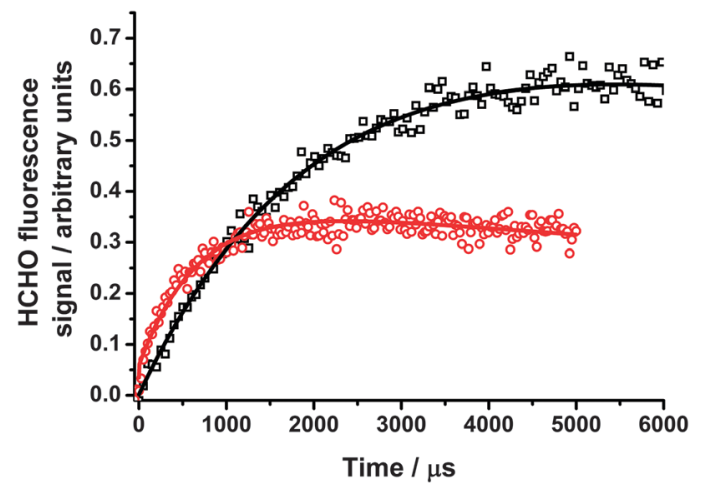

Fig. $1 \mathrm{HCHO}$ fluorescence signals at 200 Torr following photolysis of $\mathrm{CH}_{2} \mathrm{I}_{2}$ in the presence of $\mathrm{O}_{2}$ in the absence of any co-reagent (black open squares) and in the presence of $\mathrm{NO}_{2}$ (red open circles). The fits to eqn (1) are shown by the solid lines, and give $k_{\mathrm{g}}{ }^{\prime}=(460 \pm 30) \mathrm{s}^{-1}$ in the absence of any additional co-reagent and $k_{\mathrm{g}}{ }^{\prime}=(1490 \pm 50) \mathrm{s}^{-1}$ in the presence of $\mathrm{NO}_{2}$. The ratio of $\mathrm{S}_{1}$ (eqn (1)) in the presence of $\mathrm{NO}_{2}$ to that in the absence of $\mathrm{NO}_{2}$ is 0.37 .

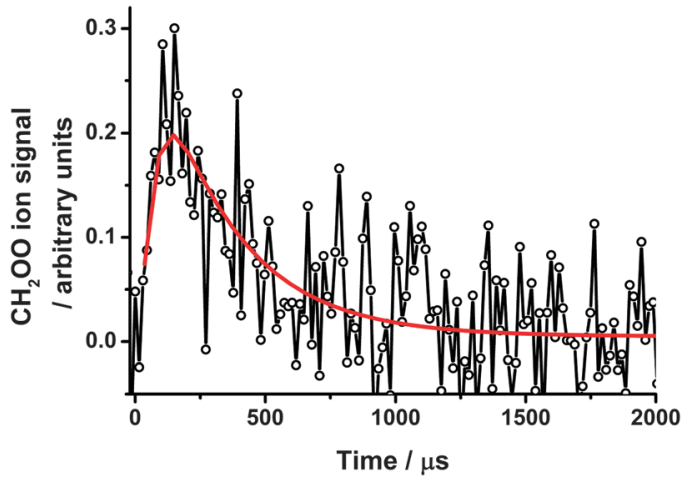

Fig. $2 \mathrm{CH}_{2} \mathrm{OO}$ ion signals at 1.5 Torr following photolysis of $\mathrm{CH}_{2} \mathrm{I}_{2}-\mathrm{O}_{2}-$ $\mathrm{N}_{2}$ in the presence of $\mathrm{SO}_{2}$, with the fit to eqn (2) (solid red line). For these data, $k^{\prime}=(3310 \pm 450) \mathrm{s}^{-1}$.

in keeping with the work of Welz et al. ${ }^{10}$ and Taatjes et al. ${ }^{11}$ Some initial HCHO production was observed owing to multi-photon photolysis of $\mathrm{CH}_{2} \mathrm{I}_{2}$ and the subsequent rapid reaction of ${ }^{3} \mathrm{CH}_{2}$ with $\mathrm{O}_{2}$, with $S_{0}$ typically no greater than $5-10 \%$ of $S_{1} \cdot{ }^{39-43}$

\section{$3.2 \mathrm{CH}_{2} \mathrm{OO}+\mathrm{SO}_{2}$}

The reaction of $\mathrm{CH}_{2} \mathrm{OO}$ with $\mathrm{SO}_{2}(\mathrm{R} 7)$ was investigated in separate experiments using the PIMS method to monitor $\mathrm{CH}_{2} \mathrm{OO}$ and the LIF method to monitor HCHO production.

$$
\mathrm{CH}_{2} \mathrm{OO}+\mathrm{SO}_{2} \rightarrow \mathrm{HCHO}+\mathrm{SO}_{3}
$$

Experiments using the PIMS method were performed at a total pressure of 1.5 Torr. Fig. 2 shows a typical decay for $\mathrm{CH}_{2} \mathrm{OO}$ observed in the presence of excess $\mathrm{SO}_{2}$, with the pseudo-firstorder rate coefficient for $\mathrm{CH}_{2} \mathrm{OO}$ decay found by least-squares fitting to eqn (2):

$$
S_{\mathrm{CH}_{2} \mathrm{OO}, t}=\frac{S_{\text {max }} k_{\text {sampling }}{ }^{\prime}}{k_{\text {sampling }}-k}\left[\exp \left(-k^{\prime} t\right)-\exp \left(-k_{\text {sampling }} t\right)\right]
$$

where $S_{\mathrm{CH}_{2} \mathrm{OO}, t}$ is the $\mathrm{CH}_{2} \mathrm{OO}$ ion signal at time $t, S_{\max }$ is the maximum $\mathrm{CH}_{2} \mathrm{OO}$ ion signal, $k^{\prime}$ is the pseudo-first-order rate coefficient for $\mathrm{CH}_{2} \mathrm{OO}$ decay, and $k_{\text {sampling }}$ is the rate coefficient representing the transport of molecules in the reactor to the ionisation region $\left(\sim 30000 \mathrm{~s}^{-1}\right.$, described in detail by Baeza-Romero et al. $\left.^{38}\right)$.

The bimolecular rate coefficient for $\mathrm{CH}_{2} \mathrm{OO}+\mathrm{SO}_{2}\left(k_{7}\right)$ determined using the PIMS method at 1.5 Torr was $(3.6 \pm 0.5) \times 10^{-11} \mathrm{~cm}^{3} \mathrm{~s}^{-1}$ (Fig. 3), similar to the value of $(3.9 \pm 0.7) \times 10^{-11} \mathrm{~cm}^{3} \mathrm{~s}^{-1}$ at 4 Torr reported by Welz et al. ${ }^{10}$ and several orders of magnitude greater than the values typically used in atmospheric models.

The LIF experiments monitoring $\mathrm{HCHO}$ production from $\mathrm{CH}_{2} \mathrm{OO}+\mathrm{SO}_{2}$ were performed over the pressure range 50-450 Torr, with $\mathrm{SO}_{2}$ concentrations in the range $2.4 \times 10^{14}$ to $1.6 \times 10^{15} \mathrm{~cm}^{-3}$. The HCHO growth (Fig. 4) was observed to display biexponential behaviour, with no decrease in the total $\mathrm{HCHO}$ yield compared to experiments performed in the absence of any co-reagent, indicating complete titration of both $\mathrm{CH}_{2} \mathrm{OO}$ and 

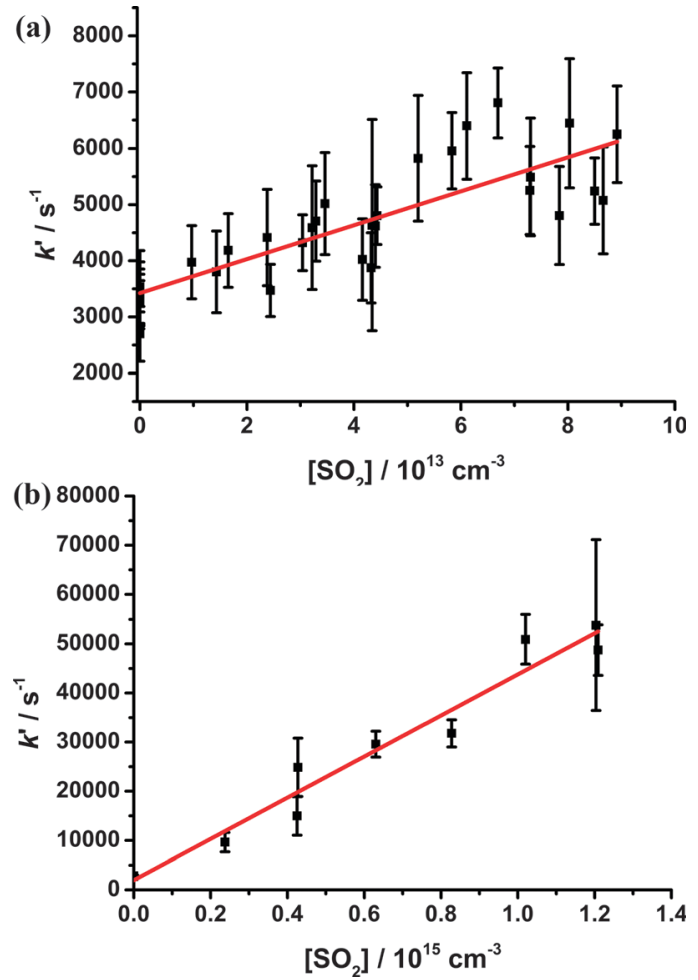

Fig. 3 (a) Pseudo-first-order rate coefficients $\left(k^{\prime}\right)$ at 1.5 Torr, derived from fits to eqn (2), for the decay of the $\mathrm{CH}_{2} \mathrm{OO}$ ion signal $(\mathrm{m} / \mathrm{z}=46$, ionised using VUV radiation at $118 \mathrm{~nm}$ ) following photolysis of $\mathrm{CH}_{2} \mathrm{I}_{2}-\mathrm{O}_{2}-\mathrm{N}_{2}$ in the presence of $\mathrm{SO}_{2}$. Error bars are $1 \sigma$. The fit to the data (shown in red) gives the bimolecular rate coefficient for $\mathrm{CHOO}+\mathrm{SO}_{2}\left(k_{7}\right)$; (b) pseudo-firstorder rate coefficients $\left(k_{\mathrm{g} 1}{ }^{\prime}\right)$ for the rapid $\mathrm{HCHO}$ production at 250 Torr following photolysis of $\mathrm{CH}_{2} \mathrm{I}_{2}-\mathrm{O}_{2}-\mathrm{N}_{2}$ in the presence of $\mathrm{SO}_{2}$ derived from fits to eqn (3). Error bars are $1 \sigma$. The fit to the data (shown in red) gives the bimolecular rate coefficient for $\mathrm{CHOO}+\mathrm{SO}_{2}\left(k_{7}\right)$.

$\mathrm{CH}_{2} \mathrm{IO}_{2}$ to $\mathrm{HCHO}$. Kinetic parameters were determined by fitting to eqn (3):

$$
\begin{aligned}
S_{\mathrm{HCHO}, t}= & S_{0}\left[\exp \left(-k_{\text {loss }} t\right)\right] \\
& +\frac{S_{1} f k_{\mathrm{g} 1}{ }^{\prime}}{k_{\mathrm{g} 1}{ }^{\prime}-k_{\text {loss }}}\left[\exp \left(-k_{\text {loss }} t\right)-\exp \left(-k_{\mathrm{g} 1}{ }^{\prime} t\right)\right] \\
& +\frac{S_{1}(1-f) k_{\mathrm{g} 2}{ }^{\prime}}{k_{\mathrm{g} 2}{ }^{\prime}-k_{\text {loss }}}\left[\exp \left(-k_{\text {loss }} t\right)-\exp \left(-k_{\mathrm{g} 2}{ }^{\prime} t\right)\right]
\end{aligned}
$$

where $S_{\mathrm{HCHO}, t}$ is the $\mathrm{HCHO}$ signal at time $t, S_{0}$ is the height of the HCHO signal at time zero, $S_{1}$ is the maximum HCHO signal, $k_{\mathrm{g} 1}{ }^{\prime}$ is the pseudo-first-order rate coefficient for the fast $\mathrm{HCHO}$ growth, $k_{\mathrm{g} 2}{ }^{\prime}$ is the pseudo-first-order rate coefficient for the slower HCHO growth, $f$ is the fractional contribution of the fast growth process to the total HCHO yield (hence $(1-f)$ is the fractional contribution of the slower growth process to the total HCHO yield), and $k_{\text {loss }}$ is the rate coefficient representing the slow loss of HCHO from the detection region via diffusion. For the $\mathrm{SO}_{2}$ experiments (conducted using a photolysis wavelength of $355 \mathrm{~nm}$ ) there was no contribution from $S_{0}$ (i.e. $S_{0}=0$ ).

The initial fast growth of HCHO displayed a linear dependence on $\left[\mathrm{SO}_{2}\right]$, while the slower growth was independent of

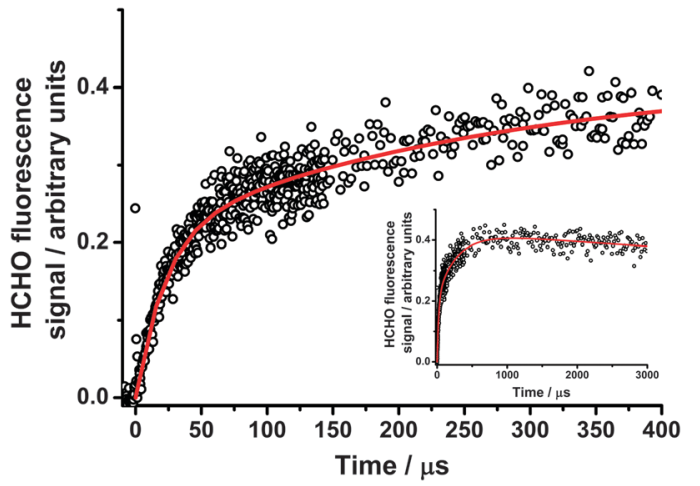

Fig. $4 \mathrm{HCHO}$ fluorescence signals at 250 Torr following photolysis of $\mathrm{CH}_{2} \mathrm{I}_{2}-\mathrm{O}_{2}-\mathrm{N}_{2}$ in the presence of $\mathrm{SO}_{2}$, with the fit to eqn (3) (solid red lines). The inset panel shows the evolution of the signal to longer times. For these data, $k_{\mathrm{g} 1}{ }^{\prime}=(45500 \pm 2240) \mathrm{s}^{-1} ; k_{\mathrm{g} 2}{ }^{\prime}=(3580 \pm 280) \mathrm{s}^{-1} ; k_{\text {loss }}=(40 \pm 9) \mathrm{s}^{-1}$; $f=(0.49 \pm 0.01) ; S_{1}=(0.43 \pm 0.01)$.

$\left[\mathrm{SO}_{2}\right]$ and at a similar rate to the observed $\mathrm{HCHO}$ production in the absence of any additional co-reagent. The yields of HCHO from the faster growth process were consistent with production from $\mathrm{CH}_{2} \mathrm{OO}+\mathrm{SO}_{2}$, while those from the slower process were consistent with production from reactions of $\mathrm{CH}_{2} \mathrm{IO}_{2}$ (i.e. reactions (R4)-(R6)). We thus determine $k_{7}$ from linear fits of $k_{\mathrm{g} 1}{ }^{\prime}$ (eqn (3)) against $\left[\mathrm{SO}_{2}\right]$. The validity of describing the system using eqn (3) is discussed in our previous work. ${ }^{26}$

Fig. 5 and Table 1 show the values of $k_{7}$ as a function of pressure. No significant dependence of $k_{7}$ on pressure was observed, with an average value of $(3.42 \pm 0.42) \times 10^{-11} \mathrm{~cm}^{3} \mathrm{~s}^{-1}$ for all experiments (PIMS and LIF) described in this work (all errors are $1 \sigma$ unless stated otherwise). Moreover, there is no significant change in the $\mathrm{HCHO}$ yield from the reaction of $\mathrm{CH}_{2} \mathrm{OO}$ with $\mathrm{SO}_{2}$ as a function of pressure, indicating there is little stabilisation of reaction products. These results are consistent with the low pressure results obtained by Welz et al. ${ }^{10}$ and theoretical work by Vereecken et al. ${ }^{13}$ and support arguments for an increased role of $\mathrm{CH}_{2} \mathrm{OO}+\mathrm{SO}_{2}$ in the atmosphere.

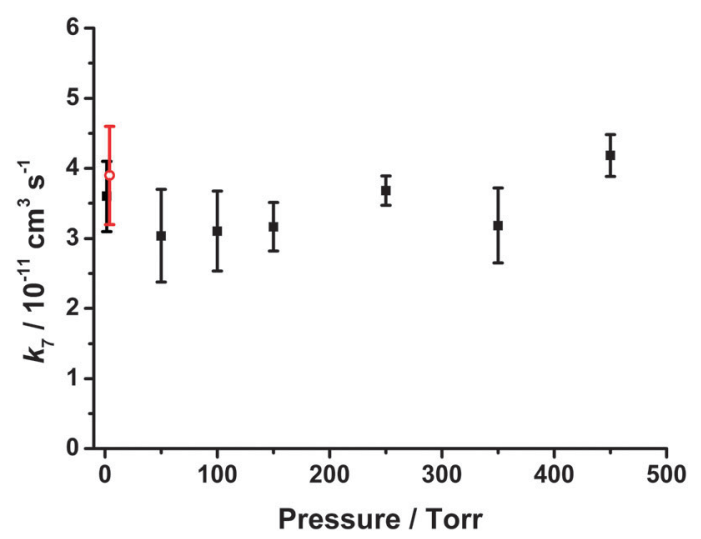

Fig. 5 Bimolecular rate coefficients for $\mathrm{CH}_{2} \mathrm{OO}+\mathrm{SO}_{2}\left(k_{7}\right)$ as a function of pressure. Error bars are $1 \sigma$. The plot includes results from the PIMS experiments (at 1.5 Torr) and the LIF experiments (pressures $\geq 50$ Torr). The data point shown by the red open circle is that determined by Welz et al. ${ }^{10}$ 
Table 1 Bimolecular rate coefficients for $\mathrm{CH}_{2} \mathrm{OO}+\mathrm{SO}_{2}\left(k_{7}\right)$ as a function of pressure. Errors are $1 \sigma$

\begin{tabular}{lcl}
\hline Pressure (Torr) & $k_{7}\left(10^{-11} \mathrm{~cm}^{3} \mathrm{~s}^{-1}\right)$ & Ref. \\
\hline $1.5^{a}$ & $3.6 \pm 0.5$ & This work \\
4 & $3.9 \pm 0.7$ & Welz et al. ${ }^{10}$ \\
50 & $3.04 \pm 0.66$ & This work \\
100 & $3.11 \pm 0.57$ & This work \\
150 & $3.17 \pm 0.34$ & This work \\
250 & $3.68 \pm 0.21$ & This work \\
350 & $3.19 \pm 0.53$ & This work \\
450 & $4.18 \pm 0.30$ & This work \\
${ }^{a}$ Data at 1.5 Torr are from the PIMS experiments. & \\
\end{tabular}

Taatjes et al. ${ }^{12}$ have also shown that the reaction of the $\mathrm{C}_{2}$ Criegee intermediate, $\mathrm{CH}_{3} \mathrm{CHOO}$, with $\mathrm{SO}_{2}$ at a pressure of 4 Torr is also significantly faster than previously expected, potentially indicating an increased role for $\mathrm{CH}_{3} \mathrm{CHOO}+\mathrm{SO}_{2}$ in the atmosphere. However, theoretical calculations predict that reactions of larger Criegee intermediates will exhibit pressure dependence, ${ }^{13}$ and that production of $\mathrm{SO}_{3}$ in reactions of larger Criegee intermediates at atmospheric pressures is unlikely owing to stabilisation of $\mathrm{SO}_{2}$-Criegee intermediate complexes to produce secondary ozonide species, thus reducing the impacts of $\mathrm{SO}_{2}+$ Criegee intermediate reactions on $\mathrm{H}_{2} \mathrm{SO}_{4}$ and sulfate aerosol production. ${ }^{13}$ Field observations and laboratory studies by Mauldin $e t a .^{23}$ indicate that larger Criegee intermediates, such as those produced in the ozonolysis of monoterpenes, do impact on atmospheric concentrations of $\mathrm{H}_{2} \mathrm{SO}_{4}$ through oxidation of $\mathrm{SO}_{2}$, but that the impacts may not be as great as those reported for $\mathrm{CH}_{2} \mathrm{OO}$, potentially owing to stabilisation of reaction products. Further work is thus required to investigate the effects of pressure on the reactions of larger Criegee intermediates. Moreover, modelled impacts of increases in the rates of Criegee intermediate reactions with $\mathrm{SO}_{2}$ are highly dependent on the competition with rates of Criegee intermediate reactions with water vapour. We thus investigate $\mathrm{CH}_{2} \mathrm{OO}+\mathrm{H}_{2} \mathrm{O}$ in Section 3.6.

\section{3 $\quad \mathrm{CH}_{2} \mathrm{I}+\mathrm{NO}_{2}$}

Production of HCHO following photolysis of $\mathrm{CH}_{2} \mathrm{I}_{2}-\mathrm{NO}_{2}-\mathrm{N}_{2}$ mixtures was examined as a function of pressure to facilitate assessment of the competition between $\mathrm{CH}_{2} \mathrm{I}+\mathrm{O}_{2}$ (R2) and $\mathrm{CH}_{2} \mathrm{I}+\mathrm{NO}_{2}$ (R8) in $\mathrm{CH}_{2} \mathrm{OO}+\mathrm{NO}_{2}$ experiments (Section 3.4).

$$
\mathrm{CH}_{2} \mathrm{I}+\mathrm{NO}_{2} \rightarrow \mathrm{HCHO}+\text { products }
$$

The production of HCHO could be described by eqn (1) (above), where $k_{\mathrm{g}}{ }^{\prime}=k_{8}\left[\mathrm{NO}_{2}\right]$, with concentrations of $\mathrm{NO}_{2}$ between $1 \times 10^{14}$ and $9 \times 10^{14} \mathrm{~cm}^{-3}$. Pseudo-first-order rate coefficients $\left(\mathrm{k}_{\mathrm{g}}{ }^{\prime}\right)$ were in the range $\sim 5000$ to $45000 \mathrm{~s}^{-1}$, and typically large compared to the rate coefficients describing HCHO production in the absence of any additional co-reagent (Section 3.1). The bimolecular rate coefficient $k_{8}$ was determined from plots of $k_{\mathrm{g}}{ }^{\prime}$ against $\left[\mathrm{NO}_{2}\right]$ at each pressure (Fig. S1, ESI $\dagger$ ), and was found to increase with increasing pressure (Fig. S2 and Table S1, ESI $\dagger$ ), with a corresponding decrease in the HCHO yield as the pressure was increased (Fig. S3, ESI $\dagger$ ).
A previous investigation of $\mathrm{CH}_{2} \mathrm{I}+\mathrm{NO}_{2}$ at pressures of 2 to 5 Torr gave a value of $k_{8}=(2.2 \pm 0.1) \times 10^{-11} \mathrm{~cm}^{3} \mathrm{~s}^{-1} \cdot{ }^{44}$ Results of this work show $k_{8}$ to be $(2.56 \pm 0.17) \times 10^{-11} \mathrm{~cm}^{3} \mathrm{~s}^{-1}$ at 50 Torr, increasing to $(5.07 \pm 0.28) \times 10^{-11} \mathrm{~cm}^{3} \mathrm{~s}^{-1}$ at 300 Torr.

The rate coefficient for reaction of $\mathrm{CH}_{2} \mathrm{I}$ radicals with $\mathrm{O}_{2}(\mathrm{R} 2)$, has been shown previously to be $\sim 1.6 \times 10^{-12} \mathrm{~cm}^{3} \mathrm{~s}^{-1}$. 45,46 Experiments to investigate $\mathrm{HCHO}$ production in the reaction of $\mathrm{CH}_{2} \mathrm{OO}$ (produced by $\mathrm{CH}_{2} \mathrm{I}+\mathrm{O}_{2}$ ) with $\mathrm{NO}_{2}$ must therefore be conducted at sufficiently high $\left[\mathrm{O}_{2}\right]$ to avoid complications owing to $\mathrm{HCHO}$ production from $\mathrm{CH}_{2} \mathrm{I}+\mathrm{NO}_{2}$.

\section{$3.4 \mathrm{CH}_{2} \mathrm{OO}+\mathrm{NO}_{2}$}

Experiments to investigate $\mathrm{CH}_{2} \mathrm{OO}+\mathrm{NO}_{2}$ (R9) kinetics were performed with sufficient $\mathrm{NO}_{2}$ concentrations $\left(1.0 \times 10^{14}\right.$ to $1.4 \times 10^{15} \mathrm{~cm}^{-3}$ ) to ensure pseudo-first-order conditions for $\mathrm{CH}_{2} \mathrm{OO}$ loss whilst also ensuring that $k_{2}\left[\mathrm{O}_{2}\right]>k_{8}\left[\mathrm{NO}_{2}\right]$ at all times to avoid potential complications owing to HCHO production through $\mathrm{CH}_{2} \mathrm{I}+\mathrm{NO}_{2}$.

$$
\begin{gathered}
\mathrm{CH}_{2} \mathrm{I}_{2}+h \nu \rightarrow \mathrm{CH}_{2} \mathrm{I}+\mathrm{I} \\
\mathrm{CH}_{2} \mathrm{I}+\mathrm{O}_{2} \rightarrow \mathrm{CH}_{2} \mathrm{OO}+\mathrm{I} \\
\mathrm{CH}_{2} \mathrm{I}+\mathrm{NO}_{2} \rightarrow \mathrm{HCHO}+\text { products } \\
\mathrm{CH}_{2} \mathrm{OO}+\mathrm{NO}_{2} \rightarrow \mathrm{HCHO}+\mathrm{NO}_{3}
\end{gathered}
$$

Fig. 1 shows the evolution of the HCHO signal following photolysis of $\mathrm{CH}_{2} \mathrm{I}_{2}-\mathrm{O}_{2}-\mathrm{N}_{2}-\mathrm{NO}_{2}$ mixtures. Experiments in which $\mathrm{NO}_{2}$ was used as a co-reagent resulted in a decrease in the total HCHO yield when compared to experiments performed in the absence of any co-reagent. We attribute this to the formation of the peroxy nitrate species $\mathrm{CH}_{2} \mathrm{IO}_{2} \mathrm{NO}_{2}$ which inhibits formation of HCHO through reactions (R4)-(R6).

Experiments performed at $273 \mathrm{~K}$ to increase the lifetime of $\mathrm{CH}_{2} \mathrm{IO}_{2} \mathrm{NO}_{2}$ with respect to dissociation to $\mathrm{CH}_{2} \mathrm{IO}_{2} \mathrm{NO}_{2}$ did not result in any significant decrease in the $\mathrm{HCHO}$ yield compared to equivalent experiments at $295 \mathrm{~K}$, indicating that the $\mathrm{CH}_{2} \mathrm{IO}_{2} \mathrm{NO}_{2}$ lifetime at $295 \mathrm{~K}$ is sufficiently long to minimise production of $\mathrm{HCHO}$ from $\mathrm{CH}_{2} \mathrm{IO}_{2}$. Thus, while there is a small contribution to the HCHO signal owing to rapid chemistry following multi-photon photolysis of $\mathrm{CH}_{2} \mathrm{I}_{2}$, the growth of $\mathrm{HCHO}$ observed following photolysis of $\mathrm{CH}_{2} \mathrm{I}_{2}-\mathrm{O}_{2}-\mathrm{N}_{2}-\mathrm{NO}_{2}$ mixtures can be attributed to $\mathrm{CH}_{2} \mathrm{OO}+\mathrm{NO}_{2}$ (R9) exclusively.

The pseudo-first-order rate coefficient for the reaction of $\mathrm{CH}_{2} \mathrm{OO}$ with $\mathrm{NO}_{2}$ was determined by least-squares fitting to eqn (1), with $k_{\mathrm{g}}{ }^{\prime}=k_{9}\left[\mathrm{NO}_{2}\right]$. The bimolecular rate coefficient for $\mathrm{CH}_{2} \mathrm{OO}+$ $\mathrm{NO}_{2}\left(k_{9}\right)$ was subsequently determined from plots of $k_{\mathrm{g}}{ }^{\prime}$ against $\left[\mathrm{NO}_{2}\right]$, as shown in Fig. 6. Fits to experimental data using the numerical integration package Kintecus ${ }^{47}$ to determine $k_{9}$, detailed in the ESI, $\uparrow$ gave results within $10 \%$ of those obtained using the analytical expression (eqn (1)).

Values for $k_{9}$ as a function of pressure are shown in Fig. 7 and Table 2. No significant dependence of $k_{9}$ on total pressure was observed over the pressure range investigated ( 25 to 300 Torr), with an average value of $k_{9}=(1.5 \pm 0.5) \times 10^{-12} \mathrm{~cm}^{3} \mathrm{~s}^{-1}$. Errors in $k_{9}$ include the $1 \sigma$ errors in the fits to the bimolecular plots at each pressure and an error of $\pm 10 \%$ to account for any differences 


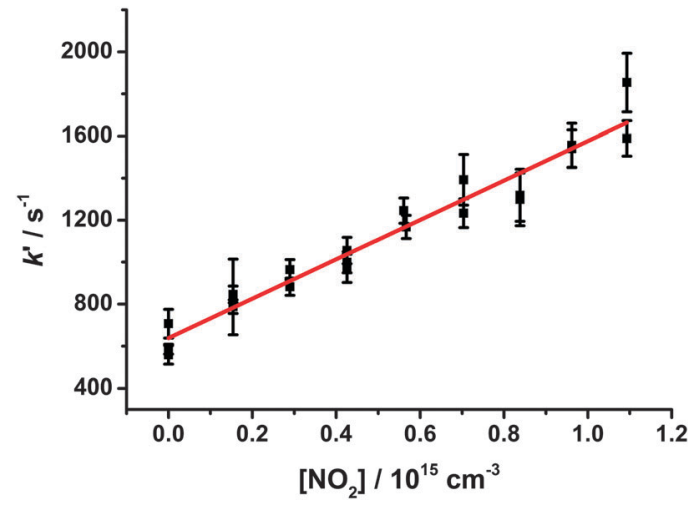

Fig. 6 Pseudo-first-order rate coefficients $\left(k_{\mathrm{g}}{ }^{\prime}\right)$ for $\mathrm{HCHO}$ production at 50 Torr, derived from fits to eqn (1), following photolysis of $\mathrm{CH}_{2} \mathrm{I}_{2}-\mathrm{O}_{2}-\mathrm{N}_{2}$ in the presence of $\mathrm{NO}_{2}$. Error bars are $1 \sigma$. The fit to the data (shown in red) gives the bimolecular rate coefficient for $\mathrm{CH}_{2} \mathrm{OO}+\mathrm{NO}_{2}\left(k_{9}\right)$.

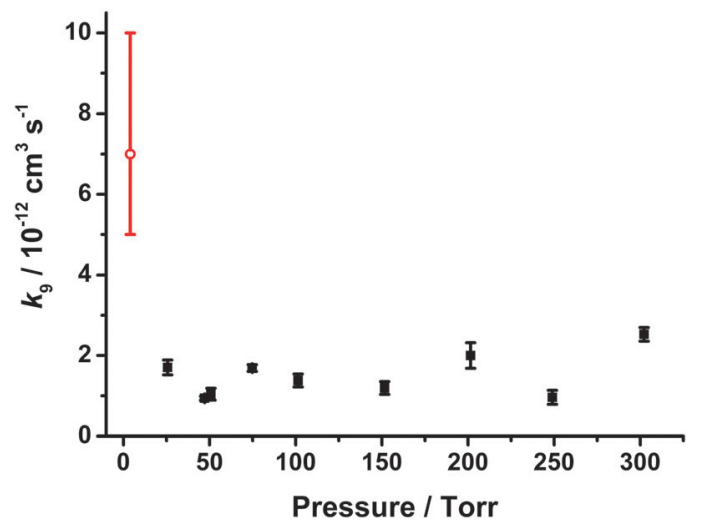

Fig. 7 Bimolecular rate coefficients for $\mathrm{CH}_{2} \mathrm{OO}+\mathrm{NO}_{2}\left(k_{9}\right)$ as a function of pressure. Error bars are $1 \sigma$. The data point shown by the red open circle is that determined by Welz et al. ${ }^{10}$

Table 2 Bimolecular rate coefficients for $\mathrm{CH}_{2} \mathrm{OO}+\mathrm{NO}_{2}\left(k_{9}\right)$ as a function of pressure. Errors include the $1 \sigma$ in the fits to the bimolecular plots and an error of $\pm 10 \%$ to account for any differences between the fits using the analytical expression and those obtained by numerical integration

\begin{tabular}{lll}
\hline Pressure (Torr) & $k_{9}\left(10^{-12} \mathrm{~cm}^{3} \mathrm{~s}^{-1}\right)$ & Ref. \\
\hline 4 & $7_{-2}^{+3}$ & Welz et al. \\
$25^{a}$ & $1.70 \pm 0.38$ & This work \\
$50^{a}$ & $1.04 \pm 0.27$ & This work \\
$50^{b}$ & $0.94 \pm 0.16$ & This work \\
$75^{a}$ & $1.69 \pm 0.28$ & This work \\
$100^{a}$ & $1.38 \pm 0.33$ & This work \\
$150^{a}$ & $1.19 \pm 0.30$ & This work \\
$200^{a}$ & $2.00 \pm 0.56$ & This work \\
$250^{a}$ & $0.96 \pm 0.29$ & This work \\
$300^{a}$ & $2.53 \pm 0.47$ & This work
\end{tabular}

${ }^{a}$ Measured using $\mathrm{N}_{2}$ as the bath gas. ${ }^{b}$ Measured using $\mathrm{O}_{2}$ as the bath gas.

between fits using the analytical expression and those obtained by numerical integration (see ESI $\dagger$ ).

Yields of $\mathrm{HCHO}$ in the presence of $\mathrm{NO}_{2}$, determined relative to experiments performed in the absence of $\mathrm{NO}_{2}$ (i.e. production

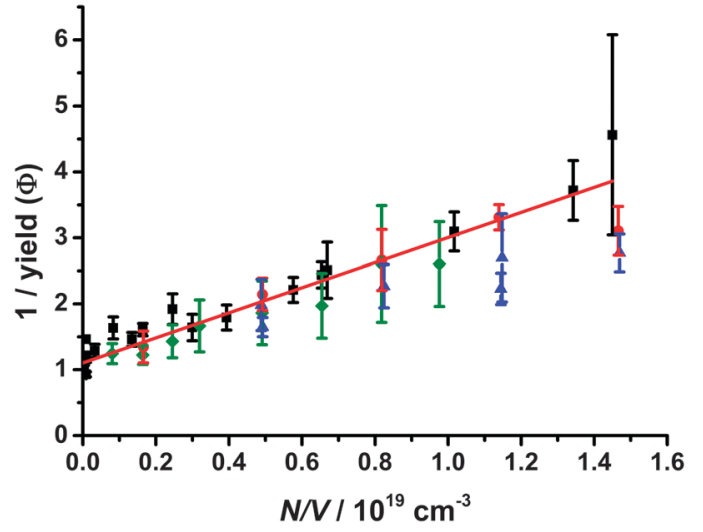

Fig. 8 Stern-Volmer plot showing (inverse) yields of $\mathrm{CH}_{2} \mathrm{OO}$ as a function of pressure from the reaction of $\mathrm{CH}_{2} \mathrm{I}$ with $\mathrm{O}_{2}$. Results from our previous work are shown for experiments monitoring iodine atom production in the system (black squares), and monitoring of $\mathrm{HCHO}$ production in experiments with $\mathrm{SO}_{2}$ (blue triangles) and $\mathrm{NO}$ (red circles), with the best fit line (red). Yields of $\mathrm{HCHO}$ from the reaction of $\mathrm{CH}_{2} \mathrm{OO}$ with $\mathrm{NO}_{2}$ (this work, green diamonds), determined relative to the $\mathrm{HCHO}$ yields in the absence of $\mathrm{NO}_{2}$ (i.e. through reactions (R3)-(R6)), suggest that there is $100 \%$ titration of $\mathrm{CH}_{2} \mathrm{OO}$ to $\mathrm{HCHO}$ in the presence of $\mathrm{NO}_{2}$ at all pressures (i.e. there is no stabilisation of reaction products), and that there is little production of $\mathrm{HCHO}$ from $\mathrm{CH}_{2} \mathrm{IO}_{2}$ in the system. The fit to our previous work (comprising data from the I atom, $\mathrm{NO}$ and $\mathrm{SO}_{2}$ experiments) gives an intercept of $1.10 \pm 0.23$ and a slope of $(1.90 \pm 0.22) \times 10^{-19} \mathrm{~cm}^{3}$. The $\mathrm{NO}_{2}$ experiments give an intercept of $1.05 \pm 0.12$ and a slope of $(1.70 \pm 0.18) \times 10^{-19} \mathrm{~cm}^{3}$.

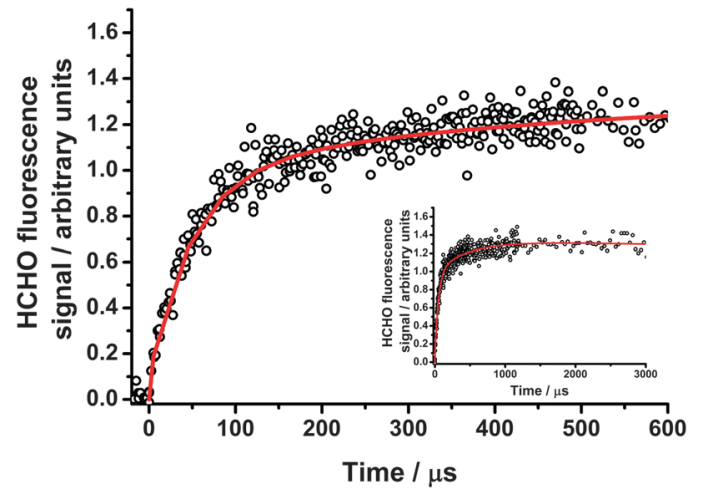

Fig. $9 \mathrm{HCHO}$ fluorescence signals at 250 Torr following photolysis of $\mathrm{CH}_{2} \mathrm{I}_{2}-\mathrm{O}_{2}-\mathrm{N}_{2}$ in the presence of $\mathrm{NO}$, with the fit to eqn (3) (solid red lines). The inset panel shows the evolution of the signal to longer times. For these data, $k_{\mathrm{g} 1}{ }^{\prime}=(24800 \pm 1400) \mathrm{s}^{-1} ; k_{\mathrm{g} 2}{ }^{\prime}=(2660 \pm 320) \mathrm{s}^{-1} ; k_{\text {loss }}=(10 \pm 2) \mathrm{s}^{-1}$; $f=(0.70 \pm 0.02) ; S_{1}=(1.33 \pm 0.01)$.

through reactions (R3)-(R6)), were consistent with the yields of $\mathrm{CH}_{2} \mathrm{OO}$ determined in our previous work ${ }^{26}$ (Fig. 8). This result demonstrates that $\sim 100 \%$ of $\mathrm{CH}_{2} \mathrm{OO}$ is titrated to $\mathrm{HCHO}$ by $\mathrm{CH}_{2} \mathrm{OO}+\mathrm{NO}_{2}$, indicating a lack of pressure dependence in $k_{9}$, and that there is insignificant $\mathrm{HCHO}$ production from $\mathrm{CH}_{2} \mathrm{IO}_{2}$ in the presence of $\mathrm{NO}_{2}$. Recent measurements by Ouyang et $a .^{21}$ have demonstrated the production of $\mathrm{NO}_{3}$ at atmospheric pressure from the reaction of $\mathrm{CH}_{2} \mathrm{OO}$ with $\mathrm{NO}_{2}$, thus also suggesting little stabilisation of reaction products to a secondary ozonide species in this system. 
No significant difference in $k_{9}$ or in yields of $\mathrm{HCHO}$ were observed between experiments performed in $\mathrm{O}_{2}$ bath gas and $\mathrm{N}_{2}$ bath gas (results shown in Table 2), providing further evidence for similar quenching of the nascent excited $\mathrm{CH}_{2} \mathrm{IO}_{2}{ }^{\#}$ species (produced in (R2)) by $\mathrm{O}_{2}$ and $\mathrm{N}_{2}$, as discussed in our previous work. ${ }^{26}$

Results for $k_{9}$ obtained in this work, while lower than those reported by Welz et al., ${ }^{10}$ are on the same order of magnitude, and demonstrate a significantly faster reaction between $\mathrm{CH}_{2} \mathrm{OO}$ and $\mathrm{NO}_{2}$ than suggested by previous indirect measurements. ${ }^{1}$

\section{$3.5 \mathrm{CH}_{2} \mathrm{OO}+\mathrm{NO}$}

Production of $\mathrm{HCHO}$ following photolysis of $\mathrm{CH}_{2} \mathrm{I}_{2}-\mathrm{O}_{2}-\mathrm{N}_{2}$ mixtures in the presence of excess NO $\left(3.6 \times 10^{14}\right.$ to $\left.1.7 \times 10^{15} \mathrm{~cm}^{-3}\right)$ exhibits biexponential growth, as shown in Fig. 9, similar to experiments with $\mathrm{SO}_{2}$. Again, no decrease in the total $\mathrm{HCHO}$ yield compared to experiments performed in the absence of any co-reagent, indicating complete titration of both $\mathrm{CH}_{2} \mathrm{OO}$ and $\mathrm{CH}_{2} \mathrm{IO}_{2}$ to $\mathrm{HCHO}$. Kinetic parameters for the processes contributing to $\mathrm{HCHO}$ production were obtained by fitting to eqn (3) (above).

The rate coefficient describing the fast HCHO growth process, $k_{\mathrm{g} 1}{ }^{\prime}$, was observed to increase linearly with increasing [NO], with the slope of a plot of $k_{\mathrm{g} 1}{ }^{\prime}$ against [NO] giving a bimolecular rate coefficient of $(1.07 \pm 0.06) \times 10^{-11} \mathrm{~cm}^{3} \mathrm{~s}^{-1}$ at 250 Torr (Fig. S4, ESI $\dagger$ ). The rate coefficient describing the slower HCHO growth, $k_{\mathrm{g} 2}{ }^{\prime}$, was found to be independent of [NO], and similar to the rate coefficient for $\mathrm{HCHO}$ production obtained in the absence of NO. Reactions of peroxy radicals $\left(\mathrm{RO}_{2}\right)$ with $\mathrm{NO}$ are well established, and are typically on the order of $10^{-12}$ to $10^{-11} \mathrm{~cm}^{3} \mathrm{~s}^{-1},{ }^{48,49}$ with a rate coefficient for $\mathrm{CH}_{3} \mathrm{O}_{2}+\mathrm{NO}$ of $7.2 \times 10^{-12} \mathrm{~cm}^{3} \mathrm{~s}^{-1},{ }^{49}$ while Welz et al. ${ }^{10}$ reported an upper limit of $6 \times 10^{-14} \mathrm{~cm}^{3} \mathrm{~s}^{-1}$ for the rate coefficient for $\mathrm{CH}_{2} \mathrm{OO}$ with NO . Thus, in contrast to the experiments with $\mathrm{SO}_{2}$, we attribute the fast $\mathrm{HCHO}$ growth to the rapid decomposition of $\mathrm{CH}_{2} \mathrm{IO}$ (R6), produced in the reaction of $\mathrm{CH}_{2} \mathrm{IO}_{2}$ with $\mathrm{NO}$ (R10) and assign $k_{10}=(1.07 \pm 0.06) \times 10^{-11} \mathrm{~cm}^{3} \mathrm{~s}^{-1}$ at 250 Torr.

$$
\begin{gathered}
\mathrm{CH}_{2} \mathrm{IO}_{2}+\mathrm{NO} \rightarrow \mathrm{CH}_{2} \mathrm{IO}+\mathrm{NO}_{2} \\
\mathrm{CH}_{2} \mathrm{IO} \rightarrow \mathrm{HCHO}+\mathrm{I}
\end{gathered}
$$

The slower HCHO growth thus contains contributions from $\mathrm{CH}_{2} \mathrm{OO}+\mathrm{I}(\mathrm{R} 3)$ and potentially $\mathrm{CH}_{2} \mathrm{OO}+\mathrm{NO}(\mathrm{R} 11)$. In the absence of NO, production of HCHO was observed with a pseudo-firstorder rate coefficient of $1860 \pm 100 \mathrm{~s}^{-1}$ (eqn (1)). On addition of up to $1.7 \times 10^{15} \mathrm{~cm}^{-3} \mathrm{NO}$, the average value for the rate coefficient describing the slow HCHO growth $\left(k_{\mathrm{g} 2}{ }^{\prime}\right.$ in eqn (3)) was $1800 \pm$ $340 \mathrm{~s}^{-1}$. Any potential influence of NO on the observed rates of $\mathrm{HCHO}$ production is assumed to be within the error of the experiment, and we thus place an upper limit of $2 \times 10^{-13} \mathrm{~cm}^{3} \mathrm{~s}^{-1}$ on the rate coefficient for reaction of $\mathrm{CH}_{2} \mathrm{OO}+\mathrm{NO}\left(k_{11}\right)$.

$$
\mathrm{CH}_{2} \mathrm{OO}+\mathrm{NO} \rightarrow \mathrm{HCHO}+\mathrm{NO}_{2}
$$

The upper limit for $k_{11}$ determined here is higher than that reported by Welz et al. $\left(k_{11}<6 \times 10^{-14} \mathrm{~cm}^{3} \mathrm{~s}^{-1}\right)$, owing to increased uncertainties associated with the biexponential fit, relatively low concentrations of NO, and higher concentrations of $\mathrm{CH}_{2} \mathrm{I}_{2}$ used in these experiments compared to those performed by Welz et al., which lead to increased iodine atom concentrations in this work and thus increased rates of HCHO production through $\mathrm{CH}_{2} \mathrm{OO}+\mathrm{I}$ (R3). In subsequent experiments (notably those used to investigate the kinetics of $\mathrm{CH}_{2} \mathrm{OO}+\mathrm{H}_{2} \mathrm{O}$ ) lower $\mathrm{CH}_{2} \mathrm{I}_{2}$ concentrations were used by changing the delivery method for $\mathrm{CH}_{2} \mathrm{I}_{2}$. There are also additional uncertainties in the rate coefficients for reactions with NO owing to the potential for production of $\mathrm{NO}_{2}$ in the gas lines leading to the reaction cell through oxidation of $\mathrm{NO}$ by $\mathrm{O}_{2}$ (the gas mixture has a residence time of $\sim 1 \mathrm{~s}$ in the gas lines leading from the mixing line to the reaction cell), leading to the potential for contributions to the observed HCHO growth from reactions involving $\mathrm{NO}_{2}$.

\section{6 $\mathrm{CH}_{2} \mathrm{OO}+\mathrm{H}_{2} \mathrm{O}$}

Welz et al. did not observe any change in the rate of $\mathrm{CH}_{2} \mathrm{OO}$ decay on addition of water vapour to the system, and reported an upper limit of $4 \times 10^{-15} \mathrm{~cm}^{3} \mathrm{~s}^{-1}$ for the rate coefficient for reaction of $\mathrm{CH}_{2} \mathrm{OO}$ with $\mathrm{H}_{2} \mathrm{O}$ (R12):

$$
\mathrm{CH}_{2} \mathrm{OO}+\mathrm{H}_{2} \mathrm{O} \rightarrow \mathrm{HCHO}+\mathrm{H}_{2} \mathrm{O}_{2}
$$

Similarly to the results of Welz et al., the addition of water vapour to the LIF experiments in this work did not result in any significant change to the rate of $\mathrm{HCHO}$ production. The total HCHO yield was also unaffected by the presence of water vapour, indicating complete titration of $\mathrm{CH}_{2} \mathrm{OO}$ and $\mathrm{CH}_{2} \mathrm{IO}_{2}$ to $\mathrm{HCHO}$ through reactions (R3)-(R6). Fig. 10 shows the HCHO fluorescence signals following photolysis of $\mathrm{CH}_{2} \mathrm{I}_{2}-\mathrm{O}_{2}-\mathrm{N}_{2}$ in the absence and presence of water vapour. While the HCHO signal is reduced in the presence of water vapour, there is no change in the kinetics and the reduction in signal is attributed to increased fluorescence quenching by water vapour.

At 200 Torr the pseudo-first-order rate coefficient for $\mathrm{HCHO}$ production was determined to be $41 \pm 15 \mathrm{~s}^{-1}$ by fitting to eqn (1), and was lower than the typical values reported in Section 3.1 as a result of lower concentrations of $\mathrm{CH}_{2} \mathrm{I}_{2}$ to reduce the rate of

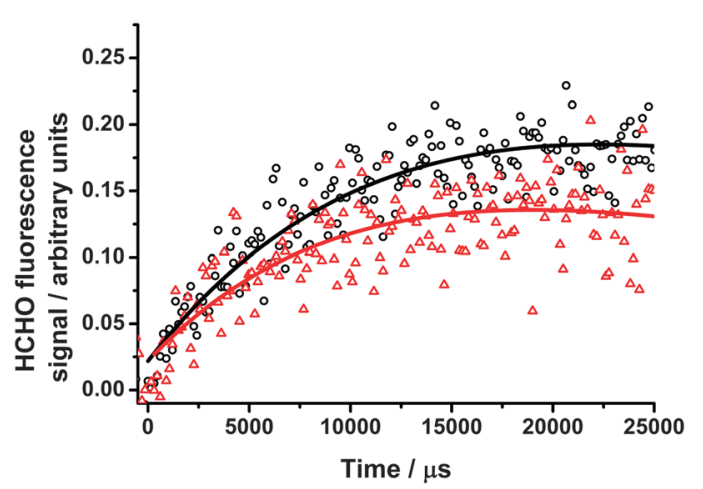

Fig. $10 \mathrm{HCHO}$ fluorescence signals at 200 Torr following photolysis of $\mathrm{CH}_{2} \mathrm{I}_{2}-\mathrm{O}_{2}-\mathrm{N}_{2}$ in the absence (black open circles) and presence of water vapour (red open triangles), with the fits to eqn (1) (solid lines). The differences in the amplitude of the signal result from the quenching of the fluorescence signal by $\mathrm{H}_{2} \mathrm{O}$. For these data, $k_{\mathrm{g}}{ }^{\prime}=(41 \pm 15) \mathrm{s}^{-1}$ in the absence of water vapour and $k_{\mathrm{g}}{ }^{\prime}=(52 \pm 13) \mathrm{s}^{-1}$ in the presence of water vapour. 
HCHO production through radical-radical reactions in the absence of water vapour. On addition of up to $1.7 \times 10^{17} \mathrm{~cm}^{-3}$ water vapour to the system, a value of $52 \pm 13 \mathrm{~s}^{-1}$ was obtained, with no obvious dependence on the concentration of water vapour added. Owing to the higher total pressures used in this work, enabling the addition of a higher number density of water vapour to the system compared to the low pressure experiments by Welz et al., we are able to place an upper limit of $9 \times 10^{-17} \mathrm{~cm}^{3} \mathrm{~s}^{-1}$ on $k_{12}$ at $295 \mathrm{~K}$ by assuming any influence of water vapour is within the error of the experiment. Ouyang et al. ${ }^{21}$ have reported a value for $k_{12}$ of $(2.5 \pm 1) \times 10^{-17} \mathrm{~cm}^{3} \mathrm{~s}^{-1}$ at 760 Torr, determined in a relative rate experiment monitoring $\mathrm{NO}_{3}$ production and using the absolute value for $k_{9}\left(\mathrm{CH}_{2} \mathrm{OO}+\mathrm{NO}_{2}\right)$ reported by Welz et al. ${ }^{10}$ $\left(7 \times 10^{-12} \mathrm{~cm}^{3} \mathrm{~s}^{-1}\right)$. Using the relative rate coefficient ratio reported by Ouyang et al., with the value for $k_{9}$ determined in this work $\left(1.5 \times 10^{-12} \mathrm{~cm}^{3} \mathrm{~s}^{-1}\right)$, a value of $k_{12}=5.4 \times 10^{-18} \mathrm{~cm}^{3} \mathrm{~s}^{-1}$ can be obtained.

Modelling studies investigating the impacts of $\mathrm{CH}_{2} \mathrm{OO}$ chemistry on the atmospheric oxidation of $\mathrm{SO}_{2}$ may therefore be underestimating the effects of increasing the rate coefficient for $\mathrm{CH}_{2} \mathrm{OO}+\mathrm{SO}_{2}$ owing to overestimation of the competition with $\mathrm{CH}_{2} \mathrm{OO}+\mathrm{H}_{2} \mathrm{O}$, resulting in more significant impacts on atmospheric production of $\mathrm{H}_{2} \mathrm{SO}_{4}$ and sulfate aerosol than indicated thus far. However, Taatjes et al. ${ }^{12}$ have shown that the anti- $\mathrm{CH}_{3} \mathrm{CHOO}$ Criegee intermediate does react with water vapour $(k=(1.0 \pm 0.4) \times$ $10^{-14} \mathrm{~cm}^{3} \mathrm{~s}^{-1}$ ), and the lack of reaction between $\mathrm{CH}_{2} \mathrm{OO}$ and water vapour may not be representative of all Criegee intermediates. Modelling of Criegee chemistry in forested regions in Finland and Germany has indicated that concentration of the $\mathrm{CH}_{2} \mathrm{OO}$ Criegee intermediate is only $\sim 20-33 \%$ of the concentrations of larger Criegee intermediates derived from monoterpenes, ${ }^{14}$ with global modelling indicating that the production rate of $\mathrm{CH}_{2} \mathrm{OO}$ comprises $\sim 40 \%$ of the total global production rate of all Criegee intermediates. ${ }^{15}$ The chemistry of larger Criegee intermediates warrants further attention.

\section{$3.7 \mathrm{CH}_{2} \mathrm{OO}+\mathrm{CH}_{3} \mathrm{CHO}$}

The reactions of Criegee intermediates with carbonyl compounds are of interest not only for their potential atmospheric relevance, but also to facilitate the use of carbonyl compounds as scavengers of Criegee intermediates in alkene ozonolysis experiments, enabling the determination of product yields of ozonolysis reactions.

Horie et al. ${ }^{50}$ studied the relative rates of $\mathrm{CH}_{2} \mathrm{OO}$ reactions with $\mathrm{CH}_{3} \mathrm{CHO}(\mathrm{R} 13)$ and $\mathrm{CF}_{3} \mathrm{COCF}_{3}$ (R14) at 730 Torr in synthetic air using FT-IR spectroscopy to monitor the decay of $\mathrm{CF}_{3} \mathrm{COCF}_{3}$ and the production of the secondary ozonide propene ozonide (methyl-1,2,4-trioxolane) from the reaction with $\mathrm{CH}_{3} \mathrm{CHO}$, and found the reaction with $\mathrm{CF}_{3} \mathrm{COCF}_{3}$ to be 13 times faster than that with $\mathrm{CH}_{3} \mathrm{CHO}$.

$$
\begin{aligned}
& \mathrm{CH}_{2} \mathrm{OO}+\mathrm{CH}_{3} \mathrm{CHO} \rightarrow \text { products } \\
& \mathrm{CH}_{2} \mathrm{OO}+\mathrm{CF}_{3} \mathrm{COCF}_{3} \rightarrow \text { products }
\end{aligned}
$$

Secondary ozonide products were observed by Horie et al. for both (R13) and (R14) at 730 Torr, while photoionisation mass spectrometry experiments by Taatjes et al. ${ }^{11}$ at 4 Torr observed a secondary ozonide product for (R14) but not for (R13). Absolute rate coefficients for $\mathrm{CH}_{2} \mathrm{OO}+\mathrm{CH}_{3} \mathrm{CHO}$ and $\mathrm{CH}_{2} \mathrm{OO}+\mathrm{CF}_{3} \mathrm{COCF}_{3}$ were measured by Taatjes et al. ${ }^{11}$ at 4 Torr in He by direct monitoring of $\mathrm{CH}_{2} \mathrm{OO}$, with results indicating the reaction with $\mathrm{CF}_{3} \mathrm{COCF}_{3}$ to be $\sim 32$ times faster than that with $\mathrm{CH}_{3} \mathrm{CHO}$ and $k_{13}=(9.4 \pm 0.7) \times 10^{-13} \mathrm{~cm}^{3} \mathrm{~s}^{-1}$ at 4 Torr. As discussed by Taatjes et al., ${ }^{11}$ the differences between the results of Horie et al. and Taatjes et al. may arise from differences in the fall-off behaviour of the two reactions, indicating pressure dependence of one or both of the reactions over the range of pressures investigated. Differences in product observations between the two studies also suggest pressure dependence in $k_{13}$. In the low pressure experiments, Taatjes et al. do not observe formation of secondary ozonide products. At 730 Torr, propene ozonide was observed as the major product of (R13), indicating collisional stabilisation of the nascent secondary ozonide at high pressures. Recent theoretical work ${ }^{22}$ has investigated the potential energy surface for the reaction of $\mathrm{CH}_{2} \mathrm{OO}$ with $\mathrm{CH}_{3} \mathrm{CHO}$, and supports the observed pressure dependence of the reaction. Reaction products are predicted to be collisionally stabilised to a secondary ozonide (SOZ) species, with significant production of the SOZ at atmospheric pressure (760 Torr) and the SOZ dominating the reaction products at pressures above 1000 Torr.

Pressure dependent kinetics are expected to be typical for reactions of larger Criegee intermediates with atmospherically relevant species, including $\mathrm{SO}_{2}$, and investigation of the $\mathrm{CH}_{2} \mathrm{OO}+\mathrm{CH}_{3} \mathrm{CHO}$ system may therefore provide insight to the behaviour of other Criegee intermediates.

In this work, we investigate $\mathrm{HCHO}$ production from $\mathrm{CH}_{2} \mathrm{OO}+$ $\mathrm{CH}_{3} \mathrm{CHO}$ (R13) at total pressures between 25 and 300 Torr and concentrations of $\mathrm{CH}_{3} \mathrm{CHO}$ in the range $2 \times 10^{14}$ to $1 \times 10^{15} \mathrm{~cm}^{-3}$. Production of $\mathrm{HCHO}$ displayed single exponential growth, and the HCHO fluorescence signal was fitted to eqn (1) (Fig. 11). Fig. 12 shows the bimolecular plot used to determine $k_{13}$ at 25 Torr, giving $k_{13}=(1.48 \pm 0.04) \times 10^{-12} \mathrm{~cm}^{3} \mathrm{~s}^{-1}$ at 25 Torr. The HCHO yield from (R13) (corrected for any $\mathrm{HCHO}$ production from $\mathrm{CH}_{2} \mathrm{IO}_{2}$ in reactions (R4)-(R6) using the results of our previous work) was observed to decrease with increasing pressure, indicating stabilisation of the $\mathrm{CH}_{2} \mathrm{OO}+\mathrm{CH}_{3} \mathrm{CHO}$ reaction product at higher pressures (R13b) and pressure dependence in $k_{13}$.

$$
\begin{aligned}
& \mathrm{CH}_{2} \mathrm{OO}+\mathrm{CH}_{3} \mathrm{CHO} \rightarrow \mathrm{CH}_{2} \mathrm{OO}-\mathrm{CH}_{3} \mathrm{CHO}^{\#} \\
& \mathrm{CH}_{2} \mathrm{OO}-\mathrm{CH}_{3} \mathrm{CHO}^{\#} \rightarrow \mathrm{HCHO}+\mathrm{CH}_{3} \mathrm{C}(\mathrm{O}) \mathrm{OH}(\mathrm{R} 13 \mathrm{a}) \\
& \mathrm{CH}_{2} \mathrm{OO}-\mathrm{CH}_{3} \mathrm{CHO}^{\#}+\mathrm{M} \rightarrow \text { propene ozonide }+\mathrm{M} \text { (R13b) }
\end{aligned}
$$

Fig. 13 shows the Stern-Volmer plot for HCHO yields from (R13), giving an intercept of $1.19 \pm 0.39$ and slope $\left(k_{13 \mathrm{~b}} / k_{13 \mathrm{a}}\right)$ of $(1.09 \pm 0.08) \times 10^{-18} \mathrm{~cm}^{3}$. Using an intercept of 1 , at 4 Torr we estimate a yield of $\mathrm{HCHO}$ of $88 \%$, with a yield of $4 \%$ at 730 Torr, reconciling the results of Taatjes et al. ${ }^{11}$ and Horie et al. ${ }^{50}$ and in agreement with theoretical work of Jalan et al. ${ }^{22}$

Owing to the decrease in $\mathrm{HCHO}$ yield with increasing pressure, assignment of the kinetics of (R13) at pressures above 25 Torr is challenging. Using the results of Taatjes et al. ${ }^{11}$ at 4 Torr $\left(k_{13}=(9.5 \pm 0.7) \times 10^{-13} \mathrm{~cm}^{3} \mathrm{~s}^{-1}\right)$, together with those 


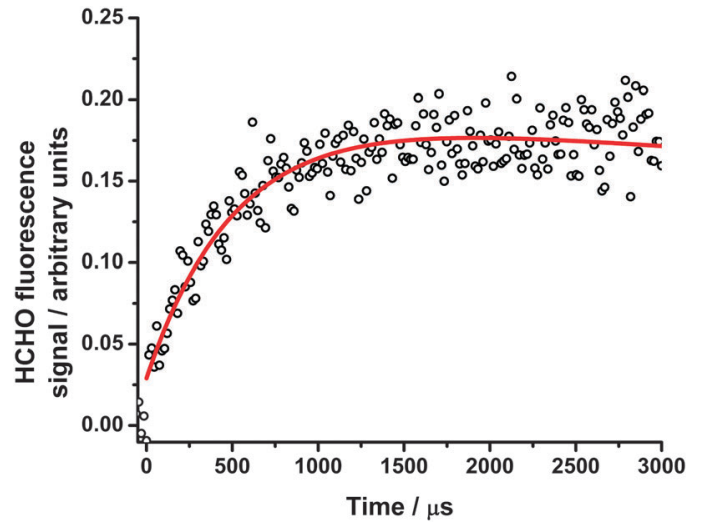

Fig. $11 \mathrm{HCHO}$ fluorescence signals at 25 Torr following photolysis of $\mathrm{CH}_{2} \mathrm{I}_{2}-\mathrm{O}_{2}-\mathrm{N}_{2}$ in the presence of $\mathrm{CH}_{3} \mathrm{CHO}$, with the fit to eqn (1) (solid red line). For these data, $k_{\mathrm{g}}{ }^{\prime}=(2040 \pm 120) \mathrm{s}^{-1}$.

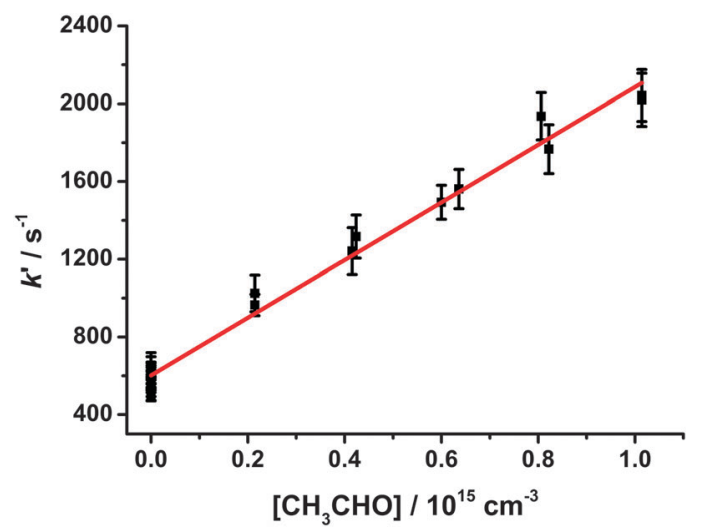

Fig. 12 Pseudo-first-order rate coefficients $\left(k_{\mathrm{g}}{ }^{\prime}\right)$ for $\mathrm{HCHO}$ production at 25 Torr, derived from fits to eqn (1), following photolysis of $\mathrm{CH}_{2} \mathrm{I}_{2}-\mathrm{O}_{2}-\mathrm{N}_{2}$ in the presence of $\mathrm{CH}_{3} \mathrm{CHO}$. Error bars are $1 \sigma$. The fit to the data (shown in red) gives the bimolecular rate coefficient for $\mathrm{CH}_{2} \mathrm{OO}+\mathrm{CH}_{3} \mathrm{CHO}\left(k_{13}\right)$.

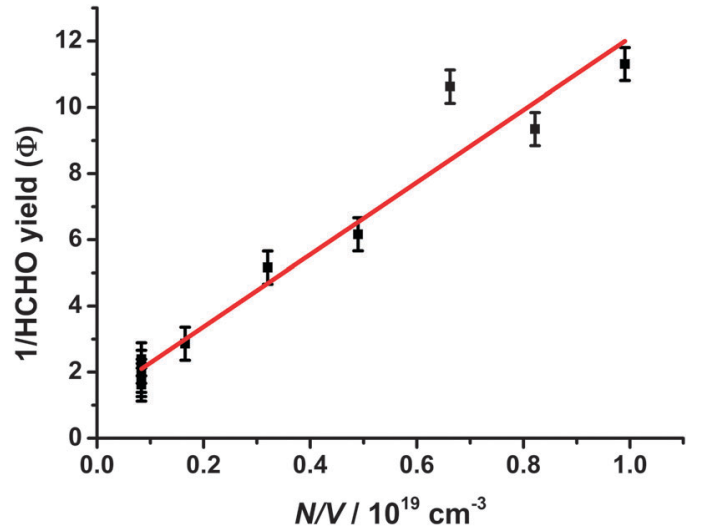

Fig. 13 Stern-Volmer analysis for $\mathrm{HCHO}$ yields from $\mathrm{CH}_{2} \mathrm{OO}+\mathrm{CH}_{3} \mathrm{CHO}$ (R13) (corrected for $\mathrm{HCHO}$ production from $\mathrm{CH}_{2} \mathrm{IO}_{2}$ chemistry) as a function of total pressure, with the fit to the data (red). Error bars are $1 \sigma$.

determined here at $25 \operatorname{Torr}\left(k_{13}=(1.48 \pm 0.04) \times 10^{-12} \mathrm{~cm}^{3} \mathrm{~s}^{-1}\right)$, 50 Torr $\left(\sim 2.2 \times 10^{-12} \mathrm{~cm}^{3} \mathrm{~s}^{-1}\right)$ and the determination of $k_{13 \mathrm{~b}} / k_{13 \mathrm{a}}$ from the Stern-Volmer plot $\left((1.09 \pm 0.08) \times 10^{-18} \mathrm{~cm}^{3}\right)$, we estimate a low pressure limit $\left(k_{13,0}\right)$ of $\sim 1.6 \times 10^{-29} \mathrm{~cm}^{6} \mathrm{~s}^{-1}$ and a high pressure limit $\left(k_{13, \infty}\right)$ of $\sim 1.7 \times 10^{-12} \mathrm{~cm}^{3} \mathrm{~s}^{-1}$ (see ESI $\dagger$ ).

\section{Conclusions}

Reactions of the $\mathrm{CH}_{2} \mathrm{OO}$ Criegee intermediate with $\mathrm{NO}_{2}$, NO, $\mathrm{SO}_{2}, \mathrm{H}_{2} \mathrm{O}$ and $\mathrm{CH}_{3} \mathrm{CHO}$ have been investigated over a range of pressures. The reactions of $\mathrm{CH}_{2} \mathrm{OO}$ with $\mathrm{NO}_{2}, \mathrm{SO}_{2}$ and $\mathrm{CH}_{3} \mathrm{CHO}$ are rapid, in agreement with recent measurements by Welz et al. ${ }^{10}$ and Taatjes et al. ${ }^{11}$ but in contrast to recommendations for atmospheric modelling based on indirect measurements. Rate coefficients for reactions of $\mathrm{CH}_{2} \mathrm{OO}$ with $\mathrm{NO}_{2}$ and $\mathrm{SO}_{2}$ are essentially independent of pressure over the pressure ranges studied in this work. The rate coefficient for $\mathrm{CH}_{2} \mathrm{OO}+\mathrm{CH}_{3} \mathrm{CHO}$ is pressure dependent, with stabilisation to form the secondary ozonide reaction products at high pressures.

We observe no evidence for reactions of $\mathrm{CH}_{2} \mathrm{OO}$ with $\mathrm{NO}$ or $\mathrm{H}_{2} \mathrm{O}$ under the conditions employed in this work, and place upper limits on rate coefficients for these reactions of $2 \times 10^{-13} \mathrm{~cm}^{3} \mathrm{~s}^{-1}$ and $9 \times 10^{-17} \mathrm{~cm}^{3} \mathrm{~s}^{-1}$, respectively. The upper limit for the rate coefficient for $\mathrm{CH}_{2} \mathrm{OO}+\mathrm{H}_{2} \mathrm{O}$ is significantly lower than has been reported previously. Earlier assessments ${ }^{2,14,15,17}$ of the impacts of increased reaction rates for $\mathrm{CH}_{2} \mathrm{OO}+\mathrm{SO}_{2}$ and $\mathrm{CH}_{2} \mathrm{OO}+\mathrm{NO}_{2}$ will therefore be lower limits owing to overestimation of the impacts of $\mathrm{CH}_{2} \mathrm{OO}+\mathrm{H}_{2} \mathrm{O}$.

\section{Acknowledgements}

The authors are grateful to the National Centre for Atmospheric Science (NCAS) and the Engineering and Physical Sciences Research Council (EPSRC, grant reference EP/J010871/1) for funding.

\section{References}

1 D. Johnson and G. Marston, Chem. Soc. Rev., 2008, 37, 699-716.

2 C. A. Taatjes, D. E. Shallcross and C. Percival, Phys. Chem. Chem. Phys., 2013, DOI: 10.1039/C3CP52842A.

3 N. M. Donahue, G. T. Drozd, S. A. Epstein, A. A. Presto and J. H. Kroll, Phys. Chem. Chem. Phys., 2011, 13, 10848-10857.

4 M. S. Alam, M. Camredon, A. R. Rickard, T. Carr, K. P. Wyche, K. E. Hornsby, P. S. Monks and W. J. Bloss, Phys. Chem. Chem. Phys., 2011, 12, 11002-11015.

5 L. Vereecken, Science, 2013, 340, 154-155.

6 T. L. Malkin, A. Goddard, D. E. Heard and P. W. Seakins, Atmos. Chem. Phys., 2010, 10, 1441-1459.

7 D. E. Heard, L. J. Carpenter, D. J. Creasey, J. R. Hopkins, J. D. Lee, A. C. Lewis, M. J. Pilling, P. W. Seakins, N. Carslaw and K. M. Emmerson, Geophys. Res. Lett., 2004, 31, L18112.

8 R. M. Harrison, J. Yin, R. M. Tilling, X. Cai, P. W. Seakins, J. R. Hopkins, D. L. Lansley, A. C. Lewis, M. C. Hunter, D. E. Heard, L. J. Carpenter, D. J. Creasey, J. D. Lee, M. J. Pilling, N. Carslaw, K. M. Emmerson, A. Redington, 
R. G. Derwent, D. Ryall, G. Mills and S. A. Penkett, Sci. Total Environ., 2006, 360, 5-25.

9 D. Stone, L. K. Whalley and D. E. Heard, Chem. Soc. Rev., 2012, 41, 6348-6404.

10 O. Welz, J. D. Savee, D. L. Osborn, S. S. Vasu, C. J. Percival, D. E. Shallcross and C. A. Taatjes, Science, 2012, 335, 204-207.

11 C. A. Taatjes, O. Welz, A. J. Eskola, J. D. Savee, D. L. Osborn, E. P. F. Lee, J. M. Dyke, D. W. K. Mok, D. E. Shallcross and C. J. Percival, Phys. Chem. Chem. Phys., 2012, 14, 10391-10400.

12 C. A. Taatjes, O. Welz, A. J. Eskola, J. D. Savee, A. M. Scheer, D. E. Shallcross, B. Rotavera, E. P. F. Lee, J. M. Dyke, D. K. W. Mok, D. L. Osborn and C. J. Percival, Science, 2013, 340, 177-180.

13 L. Vereecken, H. Harder and A. Novelli, Phys. Chem. Chem. Phys., 2012, 14, 14682-14695.

14 M. Boy, D. Mogensen, S. Smolander, L. Zhou, T. Nieminen, P. Paasonen, C. Plass-Duelmer, M. Sipila, T. Petaja, L. Mauldin, H. Berresheim and M. Kulmala, Atmos. Chem. Phys., 2013, 13, 3865-3879.

15 J. R. Pierce, M. J. Evans, C. E. Scott, S. D. D'Andrea, D. K. Farmer, E. Swietlicki and D. V. Spracklen, Atmos. Chem. Phys., 2013, 13, 3163-3176.

16 G. Sarwar, K. Fahey, R. Kwok, R. C. Gilliam, S. J. Roselle, R. Mathur, J. Xue, J. Yu and W. P. L. Carter, Atmos. Environ., 2013, 68, 186-197.

17 C. J. Percival, O. Welz, A. J. Eskola, J. D. Savee, D. L. Osborn, D. O. Topping, D. Lowe, S. R. Utembe, A. Bacak, G. McFiggans, M. C. Cooke, P. Xiao, A. T. Archibald, M. E. Jenkin, R. G. Derwent, I. Riipinen, D. W. K. Mok, E. P. F. Lee, J. M. Dyke, C. A. Taatjes and D. E. Shallcross, Faraday Discuss., 2013, DOI: 10.1039/C3FD00048F.

18 C. A. Taatjes, G. Meloni, T. M. Selby, A. J. Trevitt, D. L. Osborn, C. J. Percival and D. E. Shallcross, J. Am. Chem. Soc., 2008, 130, 11883-11885.

19 Y.-T. Su, Y.-H. Huang, H. A. Witek and Y.-P. Lee, Science, 2013, 340, 174-176.

20 J. M. Beames, F. Liu, L. Lu and M. I. Lester, J. Am. Chem. Soc., 2012, 134, 20045-20048.

21 B. Ouyang, M. W. McLeod, R. L. Jones and W. J. Bloss, Phys. Chem. Chem. Phys., 2013, 15, 17070-17075.

22 A. Jalan, J. W. Allen and W. H. Green, Phys. Chem. Chem. Phys., 2013, 15, 16841-16852.

23 R. L. Mauldin, III, T. Berndt, M. Sipilae, P. Paasonen, T. Petaja, S. Kim, T. Kurten, F. Stratmann, V. M. Kerminen and M. Kulmala, Nature, 2012, 488, 193-197.

24 T. Kurten, J. R. Lane, S. Jorgensen and H. G. Kjaergaard, J. Phys. Chem. A, 2011, 115, 8669-8681.

25 H. Huang, A. J. Eskola and C. A. Taatjes, J. Phys. Chem. Lett., 2012, 3, 3399-3403.
26 D. Stone, M. Blitz, L. Daubney, T. Ingham and P. Seakins, Phys. Chem. Chem. Phys., 2013, 15, 19119-19124.

27 H. Huang, B. Rotavera, A. J. Eskola and C. A. Taatjes, J. Phys. Chem. Lett., 2013, 4, 3824.

28 C. M. Roehl, J. B. Burkholder, G. K. Moortgat, A. R. Ravishankara and P. Crutzen, J. Geophys. Res.: Atmos., 1997, 102, 12819-12829.

29 L. J. Carpenter, W. T. Sturges, S. A. Penkett, P. S. Liss, B. Alicke, K. Hebestreit and U. Platt, J. Geophys. Res., [Atmos.], 1999, 104, 1679-1689.

30 L. J. Carpenter, Chem. Rev., 2003, 103, 4953-4962.

31 L. J. Carpenter, S. D. Archer and R. Beale, Chem. Soc. Rev., 2012, 41, 6473-6506.

32 T. J. Gravestock, M. A. Blitz, W. J. Bloss and D. E. Heard, ChemPhysChem, 2010, 11, 3928-3941.

33 R. A. Cox, J. Phys. Chem., 1972, 76, 814-820.

34 J. L. Jourdain, G. Lebras and J. Combourieu, Int. J. Chem. Kinet., 1979, 11, 569-577.

35 K. J. Hughes, M. A. Blitz, M. J. Pilling and S. H. Robertson, Proc. Combust. Inst., 2002, 29, 2431-2437.

36 D. T. Co, T. F. Hanisco, J. G. Anderson and F. N. Keutsch, J. Phys. Chem. A, 2005, 109, 10675-10682.

37 M. A. Blitz, A. Goddard, T. Ingham and M. J. Pilling, Rev. Sci. Instrum., 2007, 78, 034103.

38 M. Teresa Baeza-Romero, M. A. Blitz, A. Goddard and P. W. Seakins, Int. J. Chem. Kinet., 2012, 44, 532-545.

39 G. Hancock and V. Haverd, Chem. Phys. Lett., 2003, 372, 288-294.

40 H. M. Su, W. T. Mao and F. N. Kong, Chem. Phys. Lett., 2000, 322, 21-26.

41 U. Bley, F. Temps, H. G. Wagner and M. Wolf, Ber. Bunsen-Ges. Phys. Chem., 1992, 96, 1043-1048.

42 R. A. Alvarez and C. B. Moore, J. Phys. Chem., 1994, 98, 174-183.

43 M. A. Blitz, C. Kappler, M. J. Pilling and P. W. Seakins, Z. Phys. Chem., 2011, 225, 957-967.

44 A. J. Eskola, D. Wojcik-Pastuszka, E. Ratajczak and R. S. Timonen, J. Phys. Chem. A, 2006, 110, 12177-12183.

45 A. J. Eskola, D. Wojcik-Pastuszka, E. Ratajczak and R. S. Timonen, Phys. Chem. Chem. Phys., 2006, 8, 1416-1424.

46 A. Masaki, S. Tsunashima and N. Washida, J. Phys. Chem., 1995, 99, 13126-13131.

47 J. C. Ianni, Kintecus, Windows Version 2.80, www.kintecus.com, 2002.

48 P. D. Lightfoot, R. A. Cox, J. N. Crowley, M. Destriau, G. D. Hayman, M. E. Jenkin, G. K. Moortgat and F. Zabel, Atmos. Environ., Part A, 1992, 26, 1805-1961.

49 R. Atkinson, D. L. Baulch, R. A. Cox, J. N. Crowley, R. F. Hampson, R. G. Hynes, M. E. Jenkin, M. J. Rossi and J. Troe, Atmos. Chem. Phys., 2006, 6, 3625-4055.

50 O. Horie, C. Schafer and G. K. Moortgat, Int. J. Chem. Kinet., 1999, 31, 261-269. 